\title{
Temporal variations of black carbon in Guangzhou, China, in summer 2006
}

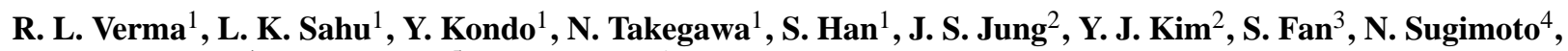 \\ M. H. Shammaa ${ }^{1}$, Y. H. Zhang $^{5}$, and Y. Zhao ${ }^{6}$ \\ ${ }^{1}$ Research Center for Advanced Science and Technology, University of Tokyo, Tokyo, Japan \\ ${ }^{2}$ Advanced Environmental Monitoring Research Center, Department of Environmental Science and Engineering, Gwangju \\ Institute of Science and Technology (GIST), Gwangju, Republic of Korea \\ ${ }^{3}$ Institute of Environmental Meteorology, School of Environmental Science and Engineering, Sun Yat-sen University, \\ Guangzhou, China \\ ${ }^{4}$ Atmospheric Remote Sensing Section, National Institute for Environmental Studies, Tsukuba, Japan \\ ${ }^{5}$ State Key Joint Laboratory of Environmental Simulation and Pollution Control, College of Environmental Science and \\ Engineering, Peking University, Beijing, China \\ ${ }^{6}$ Air Quality Research Center, University of California, Davis, USA
}

Received: 30 September 2009 - Published in Atmos. Chem. Phys. Discuss.: 18 November 2009

Revised: 23 June 2010 - Accepted: 30 June 2010 - Published: 16 July 2010

\begin{abstract}
In situ measurements of the mass concentration of black carbon (BC) and mixing ratios of carbon monoxide (CO) and carbon dioxide $\left(\mathrm{CO}_{2}\right)$ were made at Guangzhou, an urban measurement site in the Pearl River Delta (PRD), China, in July 2006. The average \pm standard deviation (SD) concentrations of $\mathrm{BC}, \mathrm{CO}$, and $\mathrm{CO}_{2}$ were $4.7 \pm 2.3 \mu \mathrm{gC} \mathrm{m}{ }^{-3}$, $798 \pm 459$ ppbv, and $400 \pm 13$ ppmv, respectively. The trends of these species were mainly controlled by synoptic-scale changes in meteorology during the campaign. Based on back trajectories, data are analyzed separately for two different air mass types representing northerly and southerly flows. The northerly air masses, which constituted $\sim 25 \%$ of the campaign, originated mostly in the PRD and hence represent observations on regional scales. On the other hand, during southerly flow $(\sim 75 \%)$, the measurements were influenced by dilution due to cleaner marine air. The diurnal patterns of $\mathrm{BC}, \mathrm{CO}$, and $\mathrm{CO}_{2}$ exhibited peak concentrations during the morning and evening hours coinciding with rush-hour traffic. The ratios of $\mathrm{OC} / \mathrm{BC}$ were lower during the morning hour peaks in the concentrations of primary pollutants due to their fresh emissions mainly from vehicular traffic in Guangzhou. The diurnal variations of $\mathrm{BC}$ observed in southerly air
\end{abstract}

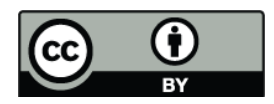

Correspondence to: Y. Kondo (y.kondo@atmos.rcast.u-tokyo.ac.jp) masses tended to follow the traffic patterns of heavy-duty vehicles (HDV) in Guangzhou, while the roles of other sources need to be investigated. The slopes of $\Delta \mathrm{BC} / \Delta \mathrm{CO}$, $\Delta \mathrm{BC} / \Delta \mathrm{CO}_{2}$, and $\Delta \mathrm{CO} / \Delta \mathrm{CO}_{2}$ observed during northerly flows were $0.0045 \mu \mathrm{gC} \mathrm{m}{ }^{-3} / \mathrm{ppbv}, 0.13 \mu \mathrm{gC} \mathrm{m}{ }^{-3} / \mathrm{ppmv}$, and $49.4 \mathrm{ppbv} / \mathrm{ppmv}$, respectively, agreeing reasonably with their respective emission ratios derived from regional emission inventories.

\section{Introduction}

A major portion of the fine-mode aerosols in the urban atmosphere are carbonaceous aerosols. Carbonaceous aerosols are generally classified into organic carbon (OC) and black carbon (BC). BC can absorb light, therefore acting as a positive radiative forcing agent in the troposphere and causing a negative radiative forcing at the earth surface (Ramanathan et al., 2008; Jacobson et al., 2000; Chuang et al., 2003; Kim et al., 2008). It has been estimated that the global mean clear-sky radiative forcing of $\mathrm{BC}$ is about $+0.4-0.8 \mathrm{~W} / \mathrm{m}^{2}$ (IPCC, 2001). BC also causes several health effects, including allergy, respiratory, and cancer-like diseases (Jansen et al., 2005; Alessandrini et al., 2006; Sugilia et al., 2007). BC and $\mathrm{CO}$ are mainly produced from incomplete combustion

Published by Copernicus Publications on behalf of the European Geosciences Union. 
of fossil fuels and biomass burning; therefore, their relative emissions can be used to characterize major emission sources influencing measurement site (Hansen et al., 1989).

Emissions of various gaseous and particulate pollutants in Asia are increasing due to rapid industrialization and urban development (Streets et al., 2003). Elevated levels of the various aerosols and gaseous species in East Asian countries are of great concern because of their impacts on the atmospheric environment on regional and continental scales, for instance a reduction in precipitation of $10-20 \%$ and increasing tendency of floods and drought (Huang et al., 2007; Menon et al., 2002). In China, major economic expansion and industrialization are occurring in mega-city clusters like Beijing, Tianjin, Bohai, and the Pearl River Delta (PRD) (Shao et al., 2006). The PRD region is a densely industrialized region where emissions from a large number of petrochemical, automobile, and electronics manufacturing units are significant. Guangzhou is the main commercial and industrial city in the PRD region, with an area of $7434.4 \mathrm{~km}^{2}$ and population of over 10 million in the year 2006.

Previous studies of anthropogenic aerosols and gaseous pollutants at Guangzhou and the surrounding urban areas mostly focused on the relationships of $\mathrm{OC}$ and $\mathrm{BC}$ and their seasonal variations (Cao et al., 2003, 2004, 2007; Duan et al., 2007; Ho et al., 2006; Cheung et al., 2005), mixing states of BC (Cheng et al., 2006), and formation of sulfate and organics (Xiao et al., 2009). Some studies have also characterized aerosol chemical composition and optical properties (Andreae et al., 2008; Liu et al., 2008; Garland et al., 2008). However, none of the previous studies have reported the relationship of $\mathrm{BC}$ to other combustion tracers (e.g., $\mathrm{CO}, \mathrm{CO}_{2}$ ), particularly in light of their emission inventories from different sources. These relationships can be used to characterize sources and also to validate the existing emission inventories of these species. There is a need to study the diurnal variations of aerosols and gaseous species for their source attributions, by making continuous time-resolved measurements.

For the first time, we report the temporal variations of hourly averaged $\mathrm{BC}, \mathrm{CO}$, and $\mathrm{CO}_{2}$ in the $\mathrm{PRD}$ region in summer in light of transient meteorological conditions and diverse emission sources. We discuss the diurnal patterns of $\mathrm{BC}, \mathrm{CO}, \mathrm{CO}_{2}$ and the ratio of $\mathrm{OC} / \mathrm{BC}$ as a qualitative indicator of the age of air masses. The estimated slopes of $\Delta \mathrm{BC} / \Delta \mathrm{CO}, \Delta \mathrm{BC} / \Delta \mathrm{CO}_{2}$, and $\Delta \mathrm{CO} / \Delta \mathrm{CO}_{2}$ are compared with respective emission ratios calculated from published emission inventories (Streets et al., 2003).

\section{Measurement}

\subsection{Observation site}

As a part of the Program of Regional Integrated Experiments of Air Quality over Pearl River Delta (PRIDE-PRD 2006) campaign, continuous measurements of $\mathrm{BC}, \mathrm{CO}$, and
$\mathrm{CO}_{2}$ concentrations were made at Guangzhou between 1 July and 31 July 2006. Figure 1a shows an emission map of $\mathrm{BC}$ from Guangzhou and the surrounding region $\left(21.75^{\circ} \mathrm{N}-24.25^{\circ} \mathrm{N} 112.25^{\circ} \mathrm{E}-114.75^{\circ} \mathrm{E}, 0.5^{\circ}\right)$ for the year 2000 (Streets et al., 2003), while Fig. 1b shows the road network in the Guangzhou urban region. In Fig. 1a and $\mathrm{b}$, a crossed circle represents the observation site, located on the 16th floor $(\sim 50 \mathrm{~m}$ above ground level (a.g.1.)) of the Guangdong Provincial Environmental Monitoring Center (GPEMC) building $\left(23.13^{\circ} \mathrm{N}, 113.26^{\circ} \mathrm{E}\right)$. Guangzhou city is surrounded by a highway and major roads including an express highway, ring road, and Dongfeng road pass through the urban region. Dongfeng is the road closest to the observation site.

\subsection{Experimental}

Measurements of $\mathrm{BC}$ or elemental carbon (EC) and $\mathrm{OC}$ mass concentrations in the fine mode $\left(\mathrm{PM}_{2.5}\right)$ were made using a semi-continuous EC-OC aerosol analyzer (RT 3015, Sunset Laboratory Inc., US) with one-hour time resolution, operated by the Gwangju Institute of Science and Technology (GIST), Gwangju, South Korea. The analysis of BC and OC was based on the National Institute for Occupational Safety and Health (NIOSH) thermal-optical transmittance (TOT) protocol for pyrolysis correction (Birch and Cary, 1996; Jeong et al., 2004; Kim et al., 2006). Ambient air samples were drawn through an inlet line fitted with a cyclone with a 2.5$\mu \mathrm{m}$ particle diameter $\left(\mathrm{PM}_{2.5}\right)$ sharp cut-off size at a flow rate of 8 LPM. Then the samples were passed through a carbonimpregnated filter (CIF) multi-channel parallel-plate denuder to remove volatile organic vapors (VOCs). Samples were collected on quartz filter paper for $44 \mathrm{~min}$ and then heated in four stages at increasing temperatures under a helium atmosphere to quantify the carbonaceous aerosols. As the OC vaporized during temperature ramping, it was oxidized to $\mathrm{CO}_{2}$ in the oxidizing oven. $\mathrm{BC}$ was oxidized to $\mathrm{CO}_{2}$ when the temperature was stepped up to $850^{\circ} \mathrm{C}$ in the oven in presence of oxygen environment. The instrument was calibrated by auto-injection of $\mathrm{CH}_{4}(5 \%$ in $\mathrm{He})$ as an internal standard. The detection limit of the instrument was estimated to be $0.4 \mu \mathrm{gC} \mathrm{m}^{-3}$ for BC, OC, or total carbon (TC), determined as three times the standard deviation $(\sigma)$ of a filtered air measurement (dynamic blank) (Kim et al., 2006; Jung et al., 2009). The quartz filter was changed every $1-2$ weeks based on the laser correction factor. The calibration constant used in the instrument to calculate mass concentrations of thermal OC and BC was $18.0 \mu \mathrm{gC}$ (Kim et al., 2006). The measurement uncertainty of the instrument was estimated to be $5 \%$. The detection limit and measurement uncertainty were similar to those reported by Polidori et al. (2006), Jeong et al. (2004), Kim et al. (2006), and Jung et al. (2009) for the EC-OC analyzer (Sunset Laboratory). 

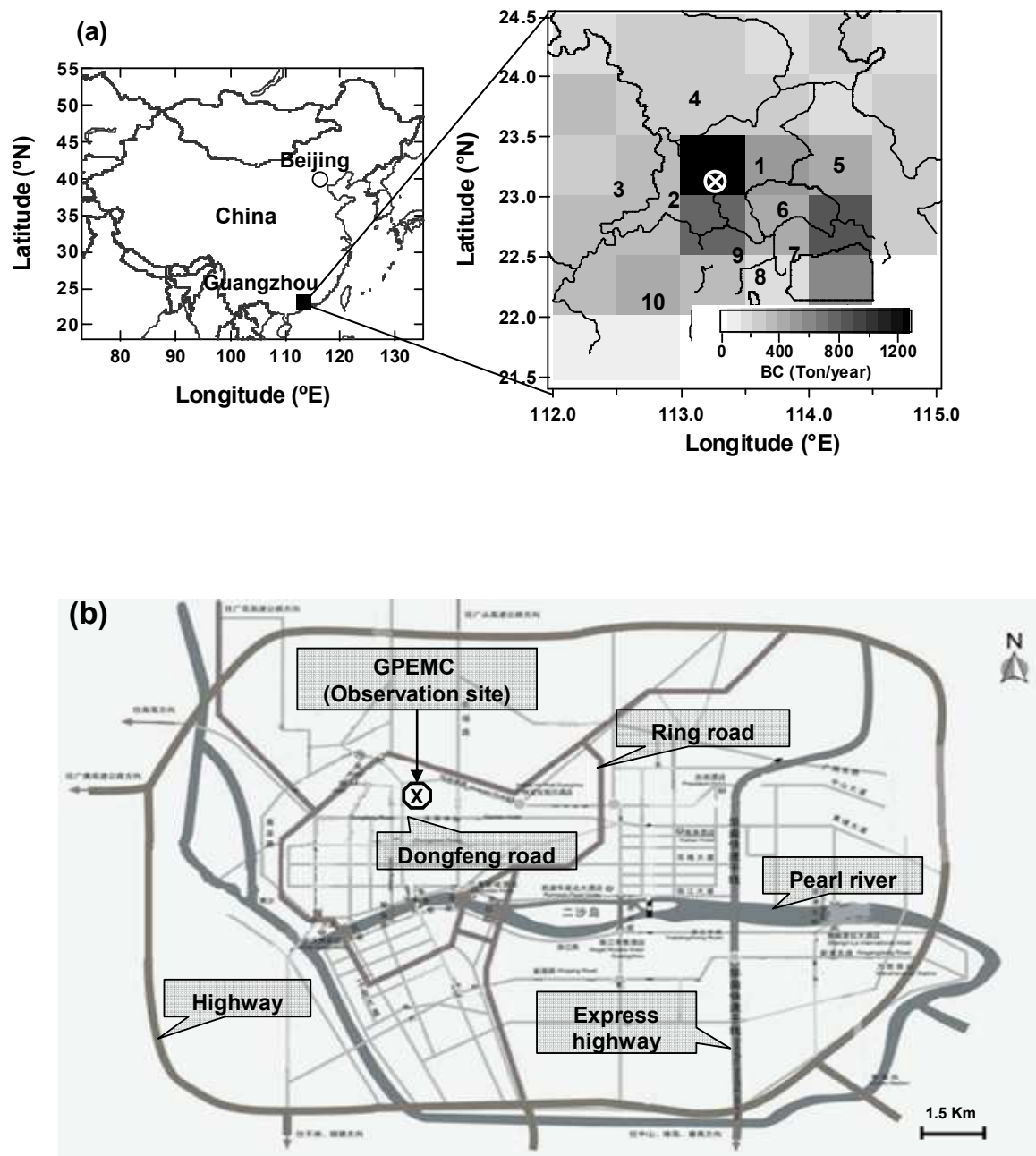

Fig. 1. (a) Spatial distribution of $\mathrm{BC}$ emissions (tons/year) in Guangzhou and surrounding areas $\left(21.75^{\circ} \mathrm{N}-24.25^{\circ} \mathrm{N}, 112.25^{\circ} \mathrm{E}-114.75^{\circ} \mathrm{E}\right)$. Numeric labels are for: 1. Guangzhou, 2. Foshan, 3. Zhouqing, 4. Qianguan, 5. Huizhou, 6. Dongguan, 7. Shenzhen, 8. Zhuhai, 9. Zhongshan, and 10. Jiangmen. The white circled cross represents the observation site. (b) Road network surrounding the observation site in Guangzhou.

Kondo et al. (2010) compared the measurements of BC using laser incandescence (single - particle soot photometer, (SP2)), refraction (refractory mass method (RMM)), thermal-optical-transmittance (TOT), and light absorption (Continuous Soot Monitoring System (COSMOS)) methods in Tokyo. They found excellent agreement between RMM versus TOT $\left(M_{\text {TOT }}=0.96 M_{\mathrm{ref}}+0.11\left(\mu \mathrm{gC} \mathrm{m}{ }^{-3}\right), r^{2}=0.88\right)$ and COSMOS versus SP2 ( $\left.M_{\mathrm{COSMOS}}=0.99 M_{\mathrm{SP} 2}-0.02\right)$ $\left.\left(\mu \mathrm{gC} \mathrm{m}^{-3}\right), r^{2}=0.97\right)$. The good agreement between the thermal and optical methods of $\mathrm{BC}$ measurements has also been reported in several previous studies (Vernkatachari et al., 2006; Park et al., 2002; Sahu et al., 2009; Yang et al., 2006; Miyazaki et al., 2008). Therefore, in this study, we have used $\mathrm{BC}$ instead of EC throughout the manuscript.
The mixing ratio of $\mathrm{CO}$ was measured using a nondispersive infrared (NDIR) absorption gas analyzer (Model 48, Thermo Environmental Instruments (TEI), US) with an integration time of one minute. $\mathrm{CO}_{2}$ concentration was measured using an NDIR-based instrument (Model LI 7000, LICor, Inc., United States) with an integration time of $10 \mathrm{sec}-$ onds (Kondo et al., 2006; Takegawa et al., 2006). A common inlet line (Teflon tube of internal diameter (ID) $\sim 6 \mathrm{~mm}$ and length $\sim 10 \mathrm{~m}$ ) was used for both analyzers from the rooftop. Because of high relative humidity levels at the measurement site in summer, air samples were passed through two sets of Nafion dryers (Perma-Pure Inc., USA) before analysis to reduce the interference of water vapor. On-site calibrations of $\mathrm{CO}$ and $\mathrm{CO}_{2}$ were performed using standard mixtures with 5 ppmv of $\mathrm{CO}$ in air and $358 \mathrm{ppmv}$ and $639 \mathrm{ppmv}$ of $\mathrm{CO}_{2}$ in air. The accuracy and precision of the $\mathrm{CO}$ measurements 
Table 1. Relative contributions (in \%) of $\mathrm{BC}, \mathrm{CO}$, and $\mathrm{CO}_{2}$ emissions from different sources in Guangzhou urban area $\left(21.75^{\circ}-24.25^{\circ} \mathrm{N}\right.$, $\left.112.25^{\circ}-114.75^{\circ} \mathrm{E}\right)$ for the year 2000 (Streets et al., 2003).

\begin{tabular}{cccccccc}
\hline & \multicolumn{2}{c}{ Domestic sector } & & \multicolumn{3}{c}{ Non-domestic sector } & \multirow{2}{*}{ Total } \\
\cline { 2 - 3 } \cline { 5 - 6 } \cline { 5 - 6 } & Fossils fuel & Biofuel & & Industry & Power & Transportation nn & \\
\hline $\mathrm{BC}$ & $10(2.0)$ & $21(4.1)$ & & $38(7.8)$ & $2(0.5)$ & $28(5.8)$ & $100(20.4)$ \\
$\mathrm{CO}$ & $3(101.7)$ & $10(337.8)$ & & $47(1624.1)$ & $2(66.1)$ & $39(1347.4)$ & $100(3477.2)$ \\
$\mathrm{CO}_{2}$ & $5(8140.0)$ & $6(10020.6)$ & & $32(50481.0)$ & $39(61507.4)$ & $17(26540.1)$ & $100(156689.1)$ \\
\hline
\end{tabular}

( ) Emissions of each species (in $\mathrm{Gg} \mathrm{yr}^{-1}$ ).

were $1.4 \%$ and 4 ppbv (at $\mathrm{CO}=400 \mathrm{ppbv}$ in $1 \mathrm{~min}$.), while for $\mathrm{CO}_{2}$ these were $0.2 \%$ and $0.3 \mathrm{ppmv}$ (at $\mathrm{CO}_{2}=400 \mathrm{ppmv}$ in $10 \mathrm{~s}$ ), respectively. Further details of these analyzers were reported by Takegawa et al. (2009).

Meteorological data were obtained from the nearest meteorological station (ZDQ-13), manufactured and operated by Sun Yet-san University, China. The accuracies of meteorological parameters like wind speed, wind direction, ambient temperature, ambient pressure, and rainfall were about $\pm 0.3 \mathrm{~m} \mathrm{~s}^{-1}, \pm 5^{\circ}$ (at wind speed $0.5 \mathrm{~m} \mathrm{~s}^{-1}$ ), $0.2^{\circ} \mathrm{C}, 0.2 \mathrm{hPa}$, and $0.4 \mathrm{~mm} \mathrm{~h}^{-1}$, respectively. The Mixed Layer Height (MLH) or the depth of the Planetary Boundary Layer (PBL) was estimated from the vertical profiles of aerosol extinction coefficient at a wavelength of $1064 \mathrm{~nm}$ from a Light Detection and Ranging (LIDAR) system operated by the National Institute for Environmental Studies (NIES), Japan. The MLH is defined as the height where the gradient of the attenuated backscattering coefficient (ATBC) at $1064 \mathrm{~nm}$ is a minimum. Details of the LIDAR measurements during the PRD campaign were discussed by Sugimoto et al. (2009).

\section{Emissions of $\mathrm{BC}, \mathrm{CO}$ and $\mathrm{CO}_{2}$}

Figure 1a shows the spatial distribution of emissions of $\mathrm{BC}$ (Streets et al., 2003). Although not shown, the emissions of $\mathrm{CO}$ and $\mathrm{CO}_{2}$ exhibited similar distributions in Guangzhou and the surrounding urban region. The observation site is located within the grid $\left(0.5^{\circ} \times 0.5^{\circ}\right)$ of highest emissions of $\mathrm{BC}$, while other major emission grids are distributed in the southeast (SE) corridors. These major BC emissions are mainly from the urban areas of Guangzhou, Foshan, Shenzhen, Zhongshan, and Jiangmen, in decreasing order. Apart from the emission sources in Guangzhou, the impact of anthropogenic activities in Foshan city could be significant, as it is the urban region closest to the measurement site. Foshan is the third largest manufacturing base in the PRD region, after Shenzhen and Guangzhou. Emissions from the sources located along the northwest (NW) and northeast (NE) sectors are less, compared to the contributions from the southern regions. Table 1 illustrates the emissions of $\mathrm{BC}, \mathrm{CO}$, and $\mathrm{CO}_{2}$ from domestic and non-domestic sectors for the year 2000 (Streets et al., 2003). The domestic sector is further sub-categorized as biofuels and fossil fuels, collectively contributing about $30 \%$ of $\mathrm{BC}$ and $10-15 \%$ each of $\mathrm{CO}$ and $\mathrm{CO}_{2}$ to the total emissions. The non-domestic sector includes emissions from industry, power generation, and transport contributing about $70 \%$ of $\mathrm{BC}$ and $85-90 \%$ of $\mathrm{CO}$ and $\mathrm{CO}_{2}$. Among these sources, the emissions from industry and transport mainly contribute to the non-domestic sector (Streets et al., 2003). In the Guangzhou urban region, the emissions of $\mathrm{BC}, \mathrm{CO}$, and $\mathrm{CO}_{2}$ from biomass burning are $0.00024,0.032$, and $0.513 \mathrm{Gg} /$ year, respectively; however, these fractions are not significant compared to the contributions from the other sectors given in Table 1. It is important to mention that these estimates are subject to large uncertainties, e.g., $484 \%$ for $\mathrm{BC}, 156 \%$ for $\mathrm{CO}$, and $16 \%$ for $\mathrm{CO}_{2}$ for China (Streets et al., 2003). However, there are sporadic burnings of automobile tires and house rubbish in Guangzhou and surrounding areas and emission estimates of such activities are not reported (http://www.mea-ren.org/ files/upload/archive/Jan.\%2015,\%202010).

As suggested by previous studies (Tan et al., 2006; Bi et al., 2003; Zhou et al., 2007; Shao, 2001) and the emission inventory of Streets et al. (2003), the transport sector could be an important source of BC in Guangzhou, as it accounts for about $30 \%$ of total BC emissions (Table 1). Figure 2 illustrates the hourly averaged diurnal variations of traffic volume comprising heavy-duty (HDV), medium-duty (MDV), and light-duty vehicles (LDV) on the Dongfeng Middle Road, recorded during 18-24 July 1999, and 12-18 October 1999 (Xie et al., 2003). Since traffic data were not recoded during the present study we rely on previous data reported for Guangzhou city (Xie et al., 2003). Although these data were recorded about 7 years before the present study and can have some limitations in this context, we assume that the diurnal pattern remains nearly unchanged. The total traffic volume is lowest during early morning hours, increases after about 07:00 h, peaks between 07:00-11:00 h, and then decreases gradually until midnight. However, HDVs show a different pattern, remaining nearly stable during the day and late evening hours (Fig. 2). There was no traffic regulation in Guangzhou for entry restrictions for heavy-duty vehicles in the city area before July 2007 (http://www.chinacourt. org/flwk/show1.php?file-id=118290) as there is in Beijing to 


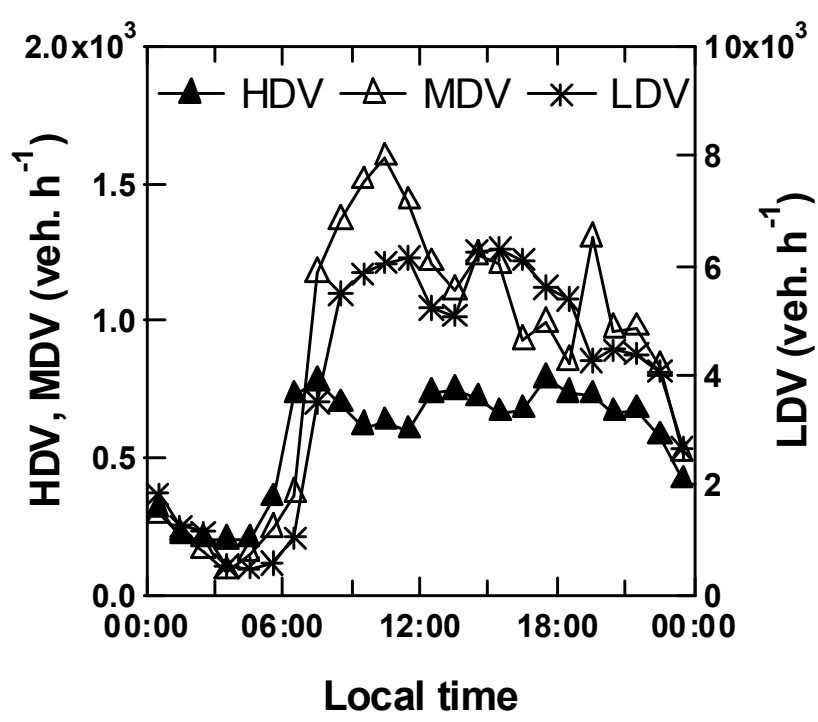

Fig. 2. Diurnal patterns of heavy-duty (HDV), medium-duty (MDV) and light-duty (LDV) vehicles on the Dongfeng middle road, recorded during 18-24 July 1999 and 12-18 October 1999 (Xie et al., 2003).

avoid traffic jams (Han et al., 2009). It is important to note that the emission factor of $\mathrm{BC}$ in HDV exhaust is significantly higher than LDV and MDV (Westerdahl et al., 2009, and references therein).

\section{Temporal variations}

Figure 3 shows temporal variations of hourly averaged $\mathrm{BC}$, $\mathrm{CO}, \mathrm{CO}_{2}$, and some meteorological parameters. The average \pm SD of wind speed, temperature, relative humidity, and pressure were $2.6 \pm 1 \mathrm{~m} \mathrm{~s}^{-1}, 31 \pm 3^{\circ} \mathrm{C}, 76 \pm 14 \%$, and $1003 \pm 5$ $\mathrm{hPa}$, respectively, during the campaign. Meteorological conditions were fairly stable, with steady wind flow $\left(\sim 3 \mathrm{~m} \mathrm{~s}^{-1}\right)$ from the South China Sea during 2-11 July. The concentrations of BC remained constant at $\sim 4 \mu \mathrm{gC} \mathrm{m}^{-3}$ for this period, except for two episodes of elevated levels in the early morning of 3 July and evening of 7 July. Observations during 12-13 July were impacted by rather weak northerly flow $\left(<2 \mathrm{~m} \mathrm{~s}^{-1}\right)$. These stagnant weather conditions could have favored the accumulation of pollutants, resulting in higher $\mathrm{BC}$ and $\mathrm{CO}$ of $\sim 12.5 \mu \mathrm{gC} \mathrm{m}{ }^{-3}$ and $\sim 1700 \mathrm{ppbv}$, respectively. A typhoon (named Billis) originating over the southern oceanic region hit the PRD on 15 July and continued until 17 July. Significant amounts of these species were likely scavenged by the rain associated with the strong wind flow during the typhoon circulation (Fig. 3). Relatively lower concentrations of pollutants were observed until 18 July due to dilution caused by the mixing of cleaner air. No significant changes in the concentrations of $\mathrm{BC}$ or $\mathrm{CO}$ were observed during 19-22 July. Later, during 23-26 July, observa-
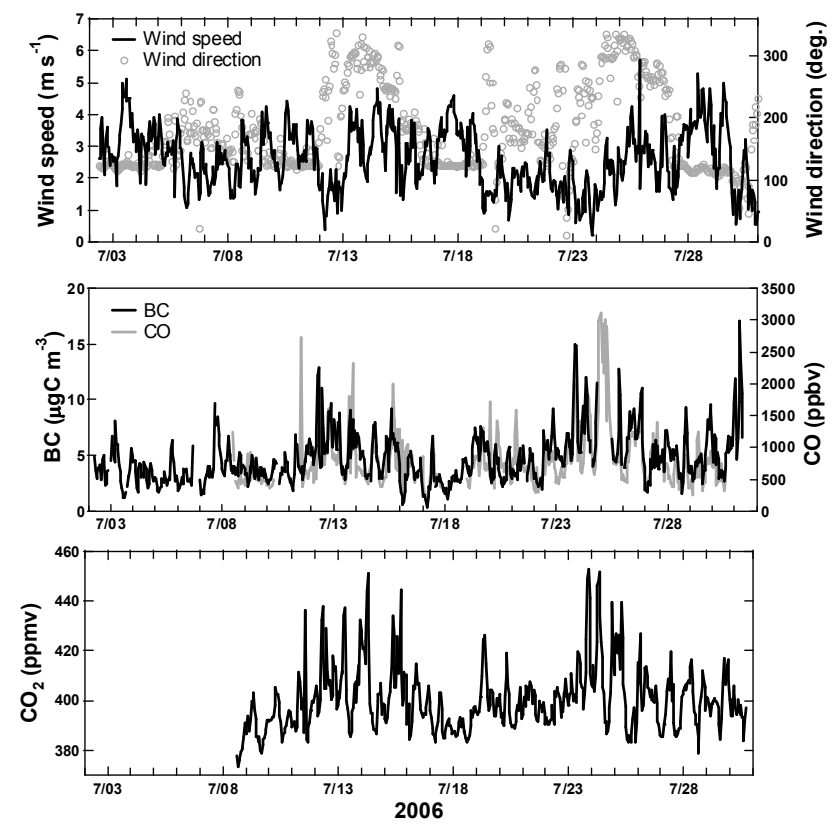

Fig. 3. Time series variations of hourly averaged concentrations of $\mathrm{BC}, \mathrm{CO}, \mathrm{CO}_{2}$ and some meteorological parameters.

tions were influenced by stagnant weather, and consequently $\mathrm{BC}$ and $\mathrm{CO}$ reached levels of $15.0 \mathrm{\mu gCm}^{-3}$ and $2500 \mathrm{ppbv}$, respectively, on some occasions. Another typhoon event, named Kaemi, arrived over the PRD with strong winds and rain during 27-28 July. The long-term trend of $\mathrm{CO}_{2}$ mixing ratio was similar to that of $\mathrm{BC}$ and $\mathrm{CO}$. To avoid any bias, measurements conducted during the episodes of rainfall have been excluded from the statistical and correlation analyses.

Generally, the concentrations of $\mathrm{BC}, \mathrm{CO}$, and $\mathrm{CO}_{2}$ appear to have been influenced by changes in meteorological conditions. To investigate the impact of long-range transport of the air masses, 3 - day isobaric back trajectories were calculated twice per day (at 00:00 local time (LT) and 14:00 LT) using the Hybrid Single Particle Lagrangian Integrated Trajectory (HYSPLIT-4) model (Draxler and Rolph, 2003). Figure 4 shows the back trajectories (once per day), each trajectory starts at 00:00 LT and $50 \mathrm{~m}$ a.g.l. at the measurement site. The pattern of trajectories at noon was almost as same as that analyzed for midnight; therefore, the latter are not been shown in Fig. 4. Based on the trajectory analyses of the entire period of observations, the air masses at the Guangzhou site have been classified into two main categories depending on the direction of transport, from northerly (red lines in Fig. 4) and southerly (blue lines in Fig. 4) directions. Air masses categorized as northerly air (about 25\% of the measurements,) arrived mostly from northwest (NW) direction and prevailed during 12-14 July and 23-26 July. However, the flow of northerly air masses was rather stagnant, as the trajectories circulated mostly within the PRD region. Therefore, the measurements of northerly air represent 


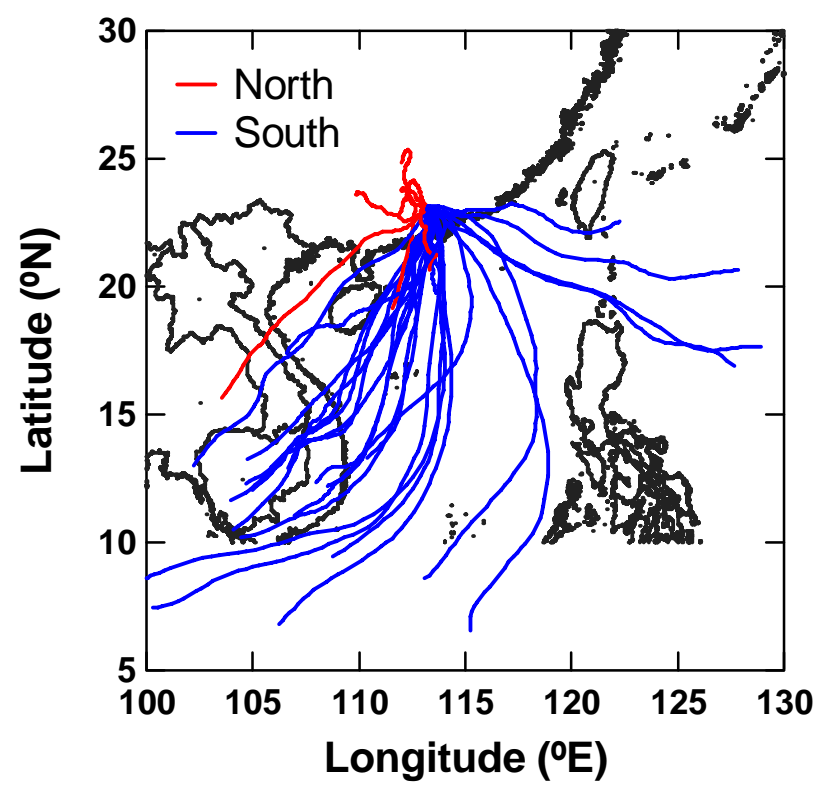

Fig. 4. Three-day back trajectories each started at 00:00 $\mathrm{h}$ from the observation site $\left(23.13^{\circ} \mathrm{N}, 113.26^{\circ} \mathrm{E}\right.$, and $50 \mathrm{~m}$ a.g.1.). The trajectories were calculated using HYSPLIT-4 model (NOAA/ARL, FNL meteorological archived dataset).

the influence of emissions from various sources in the PRD. The southerly air masses originated over the South China Sea and prevailed during 1-11 July, 16-22 July, and 27-31 July, influencing $\sim 75 \%$ of the entire campaign. The southerly flow resulted in significant dilution of primary pollutants and hence represents the observations of fresh emissions from local sources in Guangzhou.

Data measured in both northerly and southerly air masses are further classified into two categories, day (08:00-18:00 h) and night (20:00-06:00 h). We have excluded the data measured during 07:00-08:00 $\mathrm{h}$ and 19:00-20:00 $\mathrm{h}$ to avoid any biases on the measurements caused by the rapid changes in meteorological parameters. The daytime measurements represent observations of well-mixed air due to both higher boundary layer depth and wind speed. Statistics of BC, CO, and $\mathrm{CO}_{2}$ measured in different categories of air masses are presented in Table 2. The errors in the measurements are assumed to be normally distributed. Hence, in this manuscript, we have expressed the variability observed in the concentrations of the species with \pm standard deviation (SD or $\pm 1 \sigma$, within a confidence interval of $68.2 \%$ ). The average (day + night) mass concentrations of $\mathrm{BC}$ and mixing ratio of $\mathrm{CO}$ in the northerly air masses were $6.3 \mu \mathrm{gC} \mathrm{m}^{-3}$ and $1059 \mathrm{ppbv}$, while these were $4.3 \mu \mathrm{gC} \mathrm{m}{ }^{-3}$ and 693 ppbv in the southerly air masses, respectively. In the northerly air, the average levels of $\mathrm{BC}$ and $\mathrm{CO}$ were about $30 \%$ higher than those measured in the southerly air. Based on all measured data, the average concentrations of $\mathrm{BC}, \mathrm{CO}$, and $\mathrm{CO}_{2}$ were $4.7 \mu \mathrm{gC} \mathrm{m}{ }^{-3}$, 798 ppbv, and 400 ppmv, respectively.
During northerly flow, the meteorological conditions favored stagnation, causing higher levels of pollutants in ambient air. In contrast, southerly air masses were generally dominated by cleaner marine air from the South China Sea (Liu et al., 2008; Lai et al., 2007; Yeung et al., 2006). We have estimated the background concentrations, illustrated in Table 3. The background concentration is defined as the 1.25 percentile of the dataset (Kondo et al., 2006). The background concentrations of both $\mathrm{BC}$ and $\mathrm{CO}$ in the northerly air masses were higher by abouta factor of two than those estimated for southerly air masses.

\section{Diurnal variations}

The diurnal plots of the hourly average $\pm \mathrm{SD}$ of $\mathrm{BC}, \mathrm{CO}$, $\mathrm{CO}_{2}$, wind speed, $\mathrm{MLH}$, and $\mathrm{OC} / \mathrm{BC}$ ratio for both northerly and southerly air masses are shown in Fig. 5. The concentrations of $\mathrm{BC}, \mathrm{CO}$, and $\mathrm{CO}_{2}$ started increasing from the early morning hours (05:00-06:00 h). $\mathrm{BC}, \mathrm{CO}$, and $\mathrm{CO}_{2}$ attained their peaks at around 07:00-09:00 $\mathrm{h}$. As the day advances, the levels of $\mathrm{BC}, \mathrm{CO}$, and $\mathrm{CO}_{2}$ decrease gradually during the afternoon (13:00-15:00 h) due to higher vertical mixing caused by a simultaneous increase in wind speed and $\mathrm{MLH}$. In the evening hours, concentrations of $\mathrm{BC}, \mathrm{CO}$, and $\mathrm{CO}_{2}$ exhibit increasing trends and peaks at around 19:0021:00 h. The peaks of $\mathrm{BC}, \mathrm{CO}$, and $\mathrm{CO}_{2}$ concentrations coincide with rush hours, and therefore can be attributed mainly to traffic emissions. Similar features have been reported from measurements in other urban regions (Glasius et al., 2006; Park et al., 2005; Latha et al., 2004; Baumgardner et al., 2007; Dutkiewicz et al., 2009; Cao et al., 2009). OC/BC ratios of $\sim 1.0-2.0 \mu \mathrm{gC} \mathrm{m}^{-3} / \mu \mathrm{gC} \mathrm{m}{ }^{-3}$ are often associated with fresh emissions from primary sources (Turpin and Huntzicker 1991, 1995; Lin et al., 2009). As can be seen in Fig. 5, the peaks in the concentrations of $\mathrm{BC}, \mathrm{CO}$, and $\mathrm{CO}_{2}$ coincided with the lower values of the $\mathrm{OC} / \mathrm{BC}$ ratio, suggesting the influence of fresh emissions mainly from traffic. During the southerly flow, the low $\mathrm{OC} / \mathrm{BC}$ ratios of $\sim 1.0 \mu \mathrm{gC} \mathrm{m}-3 / \mu \mathrm{gC} \mathrm{m}{ }^{-3}$ during morning peak hours can be attributed to major emissions from traffic (Fig. 2). On the other hand, the higher OC/BC ratios of $\sim 2.0 \mu \mathrm{gC} \mathrm{m} / / \mu \mathrm{gC} \mathrm{m}{ }^{-3}$ during the morning rush hours of northerly flow could be due to the emissions from various sources in the PRD and also due to photochemical ageing to some extent.

In northerly air the diurnal variations of $\mathrm{BC}, \mathrm{CO}$, and $\mathrm{CO}_{2}$ were more pronounced than those in southerly air. This comparison is consistent with the variations in the meteorological parameters, for example, MLH and wind speed show stronger variation in northerly air (see Fig. 5). In southerly air, although the diurnal variations of meteorological parameters were less pronounced compared to northerly air, the daytime concentrations of $\mathrm{BC}$ and $\mathrm{CO}$ do not show any clear dependencies on local time. The effect of dilution seems 
Table 2. Statistics of $\mathrm{BC}, \mathrm{CO}$, and $\mathrm{CO}_{2}$ observed in different categories at Guangzhou. The daytime and nighttime hours were 08:0018:00 $\mathrm{h}$ and 20:00-06:00 h, respectively. To avoid any bias due to the transition phase of wind speed and MLH, the data measured during 07:00-08:00 $\mathrm{h}$ in the morning and 19:00-20:00 $\mathrm{h}$ in the evening were removed from the analysis.

\begin{tabular}{|c|c|c|c|c|c|c|c|c|c|c|c|c|c|}
\hline & & \multicolumn{4}{|c|}{$\mathrm{BC}\left(\mu \mathrm{gC} \mathrm{m}^{-3}\right)$} & \multicolumn{4}{|c|}{$\mathrm{CO}$ (ppbv) } & \multicolumn{4}{|c|}{$\mathrm{CO}_{2}$ (ppmv) } \\
\hline & & Min. & Max. & Average $\pm \mathrm{SD}$ & Median & Min. & Max. & Average \pm SD & Median & Min. & Max. & Average $\pm \mathrm{SD}$ & Median \\
\hline \multirow[t]{2}{*}{ North } & Day & 2.7 & 12.9 & $5.8 \pm 2.4$ & 5.2 & 429 & 2282 & $1025 \pm 441$ & 909 & 383 & 452 & $402 \pm 14$ & 400 \\
\hline & Night & 3.9 & 18.7 & $6.8 \pm 2.5$ & 6.3 & 443 & 3107 & $1092 \pm 737$ & 803 & 383 & 446 & $410 \pm 14$ & 408 \\
\hline \multirow[t]{2}{*}{ South } & Day & 1.2 & 9.7 & $4.1 \pm 1.4$ & 3.8 & 315 & 2729 & $734 \pm 315$ & 688 & 373 & 436 & $396 \pm 11$ & 395 \\
\hline & Night & 1.1 & 17.0 & $4.4 \pm 2.4$ & 3.8 & 263 & 1991 & $652 \pm 338$ & 556 & 380 & 452 & $397 \pm 10$ & 395 \\
\hline All data & & 1.1 & 18.7 & $4.7 \pm 2.3$ & 4.2 & 202 & 3162 & $798 \pm 459$ & 685 & 373 & 453 & $400 \pm 13$ & 398 \\
\hline
\end{tabular}
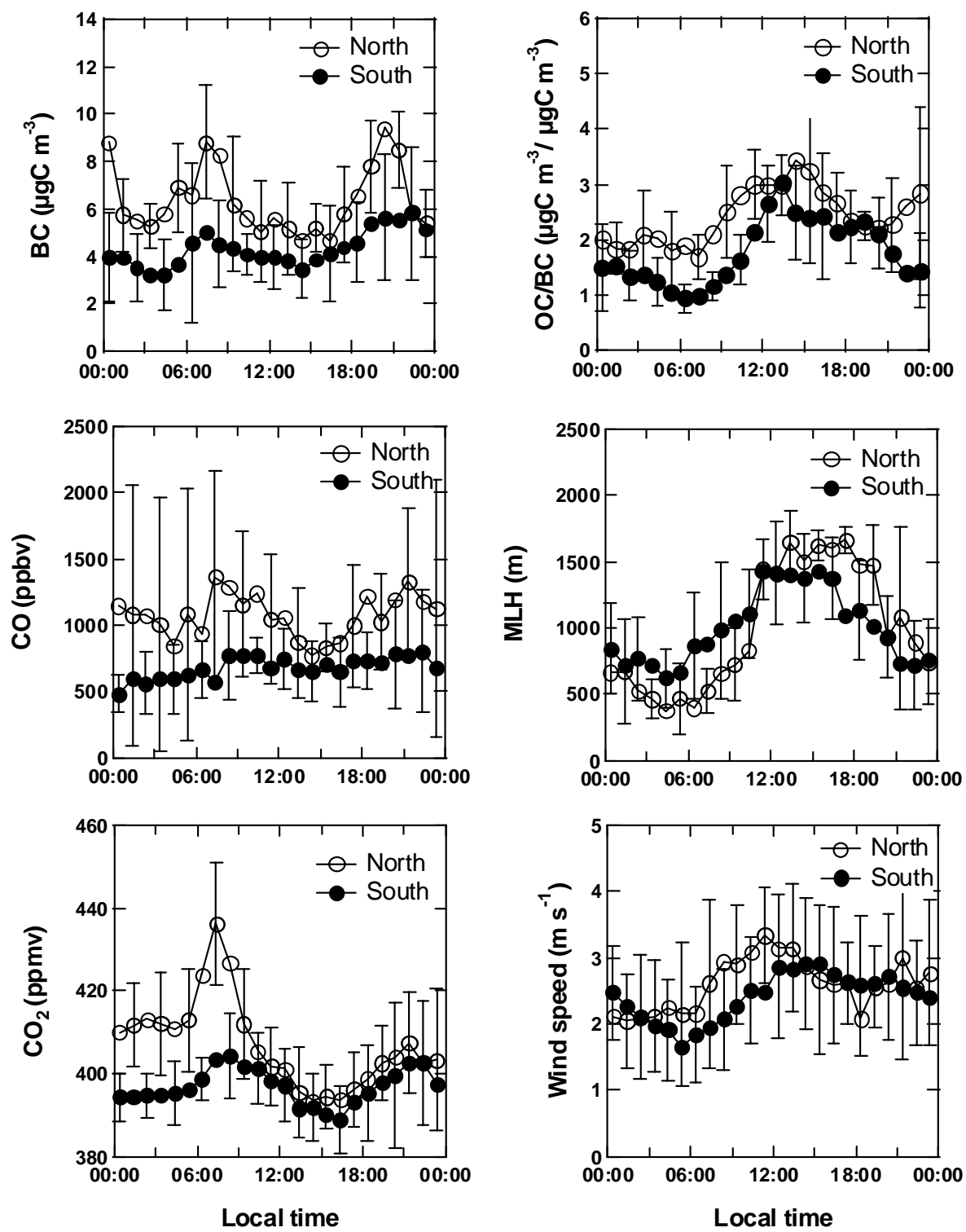

Fig. 5. Diurnal variations of hourly average $\pm \mathrm{SD}$ of $\mathrm{BC}, \mathrm{CO}, \mathrm{CO}_{2}$, wind speed, mixed layer height (MLH), and the ratios of OC/BC in northerly and northerly air masses. 
Table 3. Background concentrations (1.25 percentiles) of $\mathrm{BC}, \mathrm{CO}$, and $\mathrm{CO}_{2}$.

\begin{tabular}{llccc}
\hline & & $\mathrm{BC}\left(\mu \mathrm{gC} \mathrm{m}{ }^{-3}\right)$ & $\mathrm{CO}(\mathrm{ppbv})$ & $\mathrm{CO}_{2}(\mathrm{ppmv})$ \\
\hline \multirow{2}{*}{ North } & Day & 2.79 & 430 & 383 \\
& Night & 3.88 & 448 & 386 \\
\multirow{2}{*}{ South } & Day & 2.33 & 333 & 376 \\
& Night & 1.26 & 295 & 383 \\
All data & & 1.27 & 322 & 379 \\
\hline
\end{tabular}

to be counterbalanced due to the strong daytime emission sources near the observation site. The diurnal trend of BC in southerly flow closely follows the pattern of HDV traffic, suggesting their major influence during the daytime (Fig. 6). The combustion of diesel fuel in these vehicles is an important source of BC (Bond et al., 2004). The transport of $\mathrm{BC}$ from the strong daytime emission sources situated in the south of Guangzhou could have counterbalanced the dilution caused by higher wind and MLH (http://www.idsgroup. com/profile/pdf/industry_series/LFIndustrial2.pdf). It would be interesting to study the "weekend effect" in the concentrations of primary pollutants; however, the number of weekend days were limited in the present observations. Thus, a conclusive remark about the impact of weekend reductions in anthropogenic activities on the diurnal variations of these species is not possible.

\section{Dependence of BC on wind speed and MLH}

Apart from the local time dependence of the emissions, variations in meteorological parameters can influence the concentrations of pollutants; however, their contributions cannot be separated in a strict sense. Figure 7 shows scatter plots of $\mathrm{BC}$ with wind speed and MLH and also coded for the local time of the measurements. A small dependency of BC on wind speed was observed in both northerly and southerly air masses. On the other hand, dependencies of BC on MLH were not observed during the flows of both northerly and southerly air masses. Overall, the dependencies of BC on wind speed and MLH seem to be independent of the time of the measurements. The relationship of BC to MLH explains that the levels of BC could have been influenced by strong daytime emissions. The presence of stable aerosol layers above the boundary layer could have also inhibited the dilution of BC due to increasing MLH (Sugimoto et al., 2009)

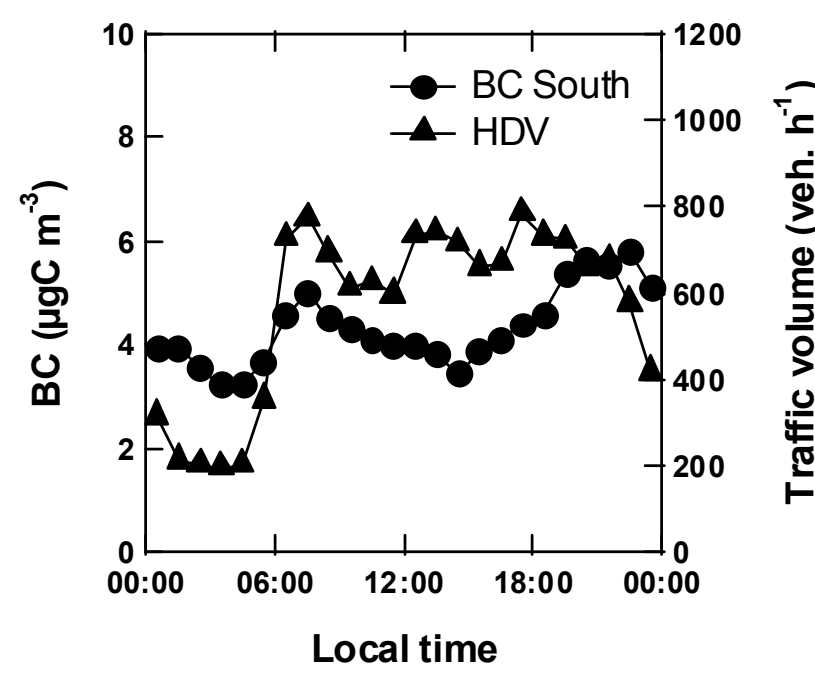

Fig. 6. Diurnal variations of hourly BC and heavy-duty vehicles (HDV) in Guangzhou. The traffic volume of HDV is an hourly average, recorded during 18-24 July 1999, and 12-18 October 1999 on the Dongfeng middle road, (Xie et al., 2003).

\section{Relationships}

\subsection{BC with $\mathrm{CO}$ and $\mathrm{CO}_{2}$}

The relationships of $\mathrm{BC}$ to $\mathrm{CO}$ and $\mathrm{CO}_{2}$ can be useful in investigating the transport of $\mathrm{BC}$ from source regions. For example, $\Delta \mathrm{CO} / \Delta \mathrm{CO}_{2}$ ratios have been used to identify the origin of air masses (Takegawa et al., 2004). Estimates of the transport efficiency of $\mathrm{BC}$ from source region to the boundary layer and from the boundary layer to the free troposphere have been based on $\mathrm{BC} / \mathrm{CO}$ correlation slopes and emission ratios calculated from emission inventories (Park et al., 2005; Sahu et al., 2008). Figure 8 shows scatter plots of the pairs $\mathrm{BC}-\mathrm{CO}, \mathrm{BC}-\mathrm{CO}_{2}$, and $\mathrm{CO}-\mathrm{CO}_{2}$ using all data. Slopes were calculated using a bi-variable linear fit regression method. The uncertainties of slopes were determined as $\pm 2 \sigma$ (within $95.4 \%$ confidence interval). Table 4 illustrates details of the linear fit regression slopes of $\triangle B C / \triangle C O$, $\Delta \mathrm{BC} / \Delta \mathrm{CO}_{2}$, and $\Delta \mathrm{CO} / \Delta \mathrm{CO}_{2}$. The slopes of $\Delta \mathrm{BC} / \Delta \mathrm{CO}$ and $\Delta \mathrm{BC} / \Delta \mathrm{CO}_{2}$ of daytime data are lower than those at nighttime in both types of air masses, whereas $\Delta \mathrm{CO} / \Delta \mathrm{CO}_{2}$ shows the opposite pattern (Table 4). Reliable $\Delta \mathrm{BC} / \Delta \mathrm{CO}$ slopes are useful for assessing long-range transport of $\mathrm{BC}$ with reference to $\mathrm{CO}$. The linear fit regression slopes of $\Delta \mathrm{BC} / \Delta \mathrm{CO}, \Delta \mathrm{BC} / \Delta \mathrm{CO}_{2}$, and $\Delta \mathrm{CO} / \Delta \mathrm{CO}_{2}$ over the whole dataset are $0.0054 \mu \mathrm{gC} \mathrm{m} \mathrm{m}^{-3} / \mathrm{ppbv}, 0.14 \mu \mathrm{gC} \mathrm{m} \mathrm{m}^{-3} / \mathrm{ppmv}$, and $46.4 \mathrm{ppbv} / \mathrm{ppmv}$, respectively. Overall, the moderate correlations between $\mathrm{BC}-\mathrm{CO}, \mathrm{BC}-\mathrm{CO}_{2}$, and $\mathrm{CO}-\mathrm{CO}_{2}$ are expected at the observation site in Guangzhou, where measurements were influenced by the emissions from various sources. 
Table 4. Observed BC-CO, BC- $\mathrm{CO}_{2}$, and $\mathrm{CO}-\mathrm{CO}_{2}$ linear regressions slopes $( \pm 2 \sigma$, within $95.4 \%$ confidence interval $)$.

\begin{tabular}{|c|c|c|c|c|c|c|c|}
\hline & & \multicolumn{2}{|c|}{$\Delta \mathrm{BC} / \Delta \mathrm{CO}\left(\mu \mathrm{gC} \mathrm{m}{ }^{-3} / \mathrm{ppbv}\right)$} & \multicolumn{2}{|c|}{$\Delta \mathrm{BC} / \Delta \mathrm{CO}_{2}\left(\mu \mathrm{gC} \mathrm{m}{ }^{-3} / \mathrm{ppmv}\right)$} & \multicolumn{2}{|c|}{$\Delta \mathrm{CO} / \Delta \mathrm{CO}_{2}(\mathrm{ppbv} / \mathrm{ppmv})$} \\
\hline & & Slope & $r^{2}$ & Slope & $r^{2}$ & Slope & $r^{2}$ \\
\hline \multirow[t]{2}{*}{ North } & Day & $0.0045 \pm 0.0008$ & 0.68 & $0.13 \pm 0.02$ & 0.62 & $49.4 \pm 6.2$ & 0.60 \\
\hline & Night & $0.0069 \pm 0.0016$ & 0.58 & NA & - & NA & - \\
\hline \multirow[t]{2}{*}{ South } & Day & $0.0051 \pm 0.0010$ & 0.59 & $0.12 \pm 0.02$ & 0.55 & $57.4 \pm 3.8$ & 0.46 \\
\hline & Night & $0.0070 \pm 0.0008$ & 0.75 & $0.21 \pm 0.02$ & 0.76 & $34.9 \pm 3.0$ & 0.67 \\
\hline \multirow[t]{2}{*}{ All data } & Day & $0.0045 \pm 0.0010$ & 0.51 & $0.13 \pm 0.02$ & 0.57 & $53.2 \pm 3.8$ & 0.50 \\
\hline & Night & $0.0067 \pm 0.0008$ & 0.72 & $0.16 \pm 0.02$ & 0.55 & NA & - \\
\hline All data & & $0.0054 \pm 0.0004$ & 0.61 & $0.14 \pm 0.02$ & 0.58 & $46.4 \pm 3.0$ & 0.45 \\
\hline
\end{tabular}

NA: not available.
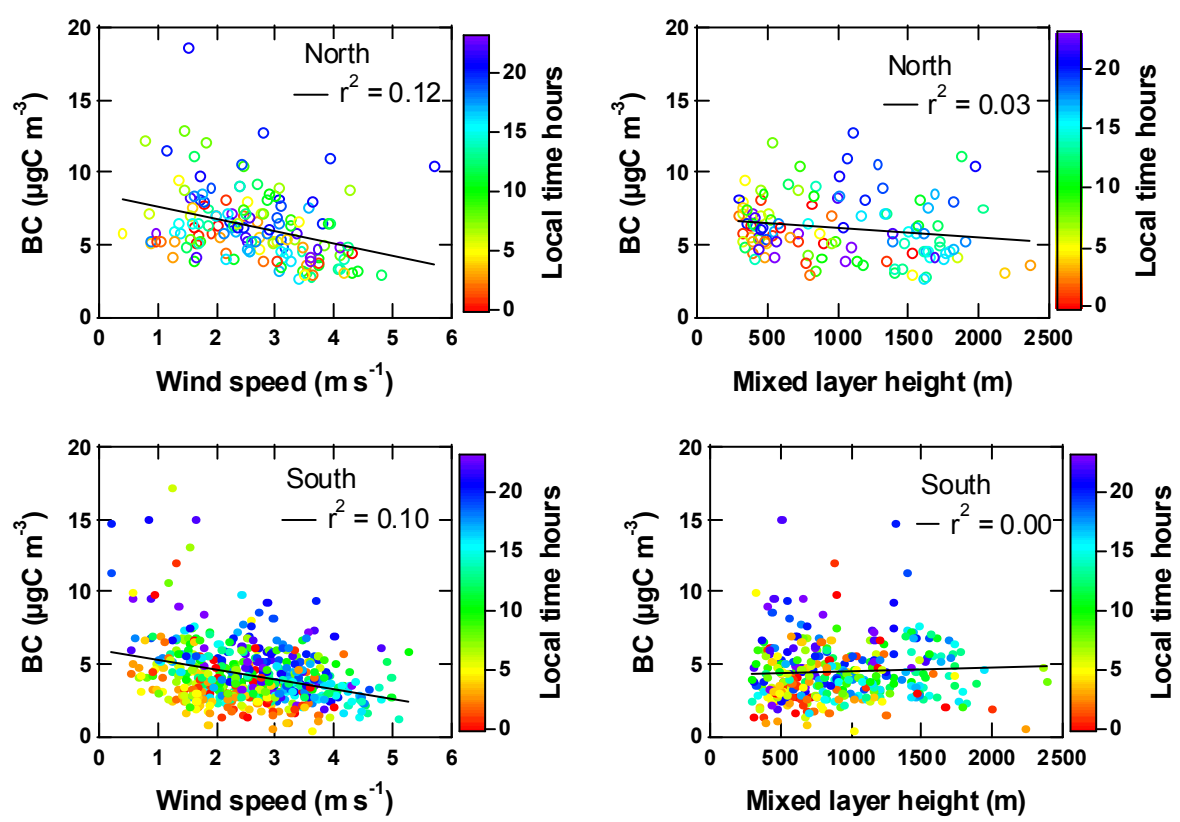

Fig. 7. Scatter plots of BC with wind speed and MLH. Northerly and southerly air masses are represented by open and closed circles, respectively. The vertical color bar represents the local time of measurements of BC.

\section{Comparisons}

\subsection{Guangzhou and Beijing}

Guangzhou and Beijing are two major urban regions of China where vehicular emissions can be an important source of ambient BC (Streets et al., 2003). In this study, we have compared the diurnal relations of $\mathrm{BC}$ in southerly flows with the traffic of heavy-duty vehicles in both cities (see Fig. 9). Similar to our observations, the diurnal variation of BC follows the traffic of heavy-duty diesel trucks (HDDTs) in Beijing (Han et al., 2009). In Beijing, the concentration of BC shows a diurnal cycle opposite to that observed in Guangzhou, as it was observed to be higher (lower) during the night (day). Similarly, the traffic volume shows this opposite diurnal pat- tern in these cities. Kondo et al. (2006) also report a close relationship of ambient BC with traffic in Tokyo. The present and previous studies in urban regions suggest that the concentrations of ambient BC are mainly controlled by the emissions from heavy duty-vehicles.

\subsection{Previous observations}

For the first time we report hourly time-resolved measurements of BC at Guangzhou. Here we compare the average $\mathrm{BC}$ of northerly flows of the present study with previous measurements conducted at different sites in Guangzhou during the summer (Fig. 10). The BC concentration of $6.2 \mu \mathrm{gC} \mathrm{m}^{-3}$ in northerly flows of this study agrees well with the average of $6.0 \mu \mathrm{gC} \mathrm{m}^{-3}$ (range $4.6-7.9 \mu \mathrm{gC} \mathrm{m}^{-3}$ ) of all other 

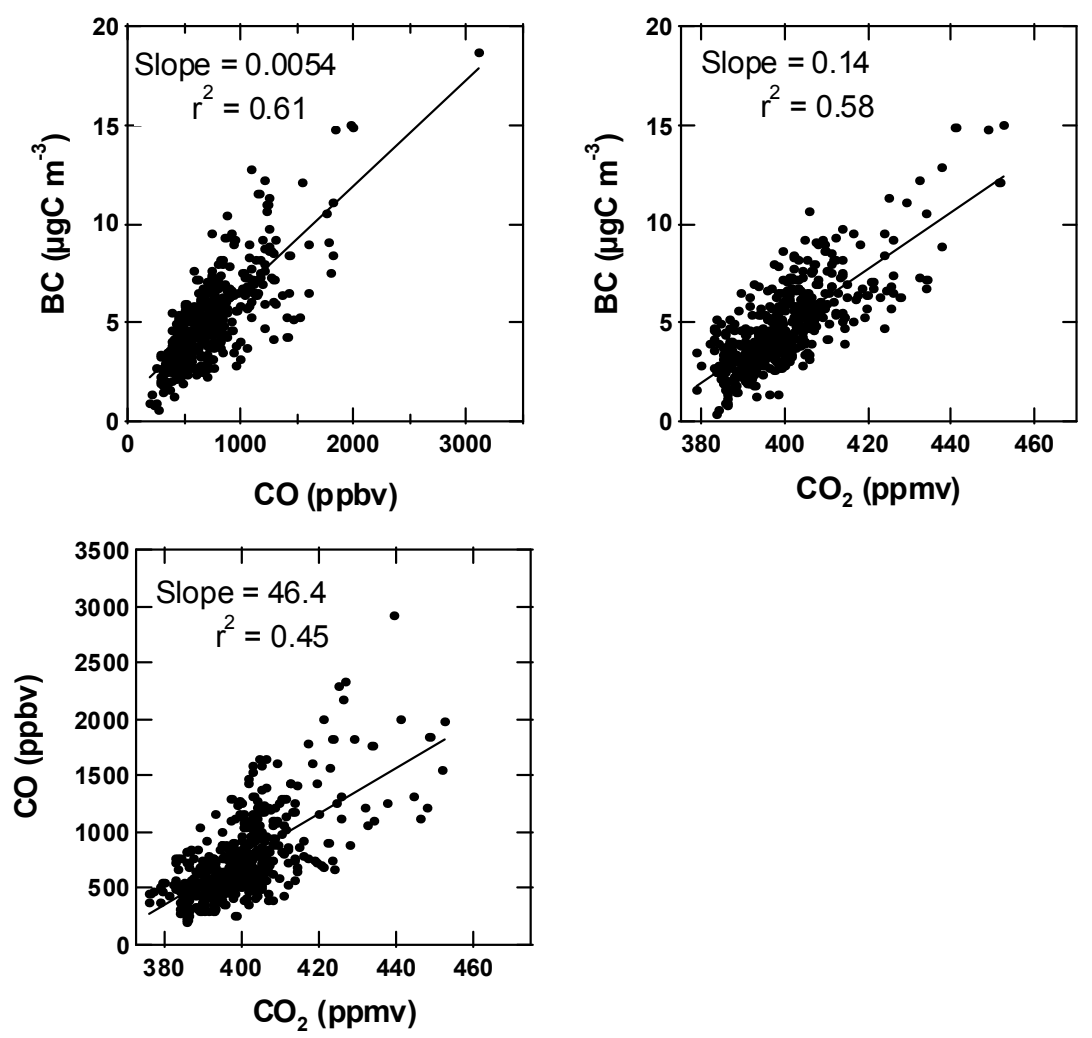

Fig. 8. Scatter plots of $\mathrm{BC}-\mathrm{CO}, \mathrm{BC}-\mathrm{CO}_{2}$, and $\mathrm{CO}-\mathrm{CO}_{2}$ in all dataset measured during the campaign.
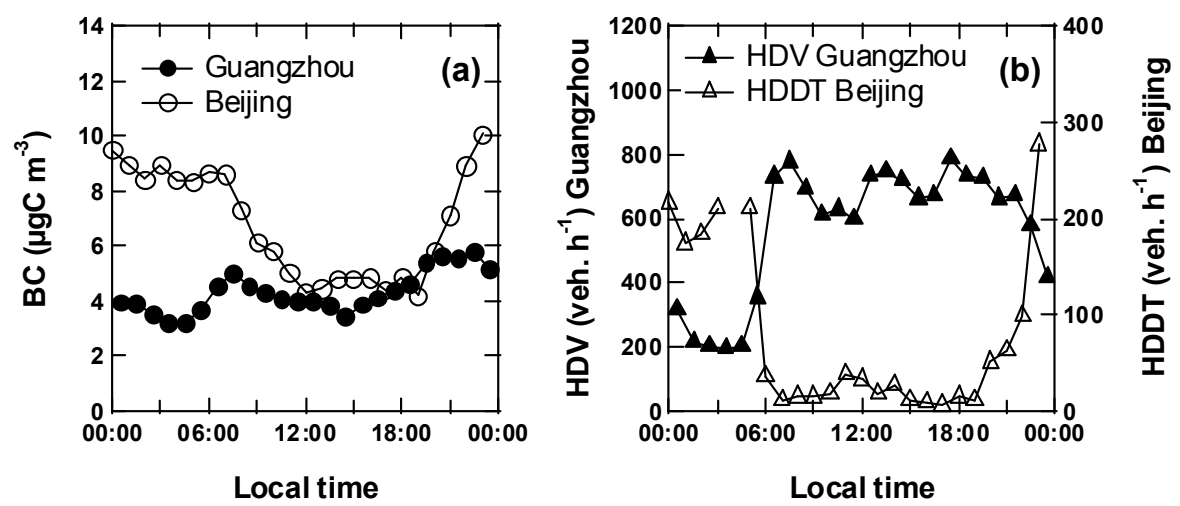

Fig. 9. Diurnal variations of (a) BC and (b) heavy-duty vehicles (HDV) in Guangzhou and heavy-duty diesel trucks (HDDT) in Beijing. The traffic volume of HDV includes buses and trucks, while HDDT is heavy-duty diesel trucks.

sites in Guangzhou (Fig. 10), situated at Zhongshan University (8 km from GPEMC), Liwan $(5 \mathrm{~km})$, Wushan $(19 \mathrm{~km})$, Huangpu $(\sim 17 \mathrm{~km})$, and Longgui $(\sim 28 \mathrm{~km})$ (Duan et al., 2007; Cao et al., 2003, 2004). Hence the average BC of northerly flows represents the level of $\mathrm{BC}$ emissions in the PRD region.

A comparison of observed $\mathrm{BC}$ and $\triangle \mathrm{BC} / \Delta \mathrm{CO}$ with that reported for other major urban regions of Asia is shown in Table 5. The BC mass concentration and slopes of
$\Delta \mathrm{BC} / \Delta \mathrm{CO}$ at Guangzhou are comparable to those observed in Beijing (China), Gwanju (South Korea), Hyderabad (India), Karachi (Pakistan), and Tokyo (Japan). These results are expected, as traffic emissions are an important source of $\mathrm{BC}$ and $\mathrm{CO}$ in these urban regions. The values of $\Delta \mathrm{BC} / \Delta \mathrm{CO}_{2}$ and $\Delta \mathrm{CO} / \Delta \mathrm{CO}_{2}$ at Guangzhou (Table 4) agree reasonably with $0.12-0.19 \mu \mathrm{gC} \mathrm{m} \mathrm{m}^{-3}$ ppmv and $30.2-$ $43.9 \mathrm{ppbv} / \mathrm{ppmv}$, respectively, in Beijing (Han et al., 2009). 
Table 5. Concentrations of $\mathrm{BC}$ aerosol and linear fit regression slopes measured in major urban regions of Asia.

\begin{tabular}{lllll}
\hline $\begin{array}{l}\text { Location and } \\
\text { measurement period }\end{array}$ & $\begin{array}{l}\mathrm{BC} \\
\left(\mu \mathrm{gC} \mathrm{m}{ }^{-3}\right)\end{array}$ & $\begin{array}{l}\Delta \mathrm{BC} / \Delta \mathrm{CO} \\
\left(\mu \mathrm{gC} \mathrm{m}{ }^{-3} / \mathrm{ppbv}\right)\end{array}$ & $\begin{array}{l}\text { Method of } \\
\mathrm{BC} \text { analysis }\end{array}$ & References \\
\hline $\begin{array}{l}\text { Guangzhou, China (Jul 2006) } \\
\text { Guangzhou, China (Oct-Nov 2004) }\end{array}$ & 4.7 & 0.0054 & TOT & Present study \\
Beijing, China (2005-2006) & 6.1 & 0.0079 & TOT & Andreae et al. (2008) \\
Tokyo, Japan (2003-2005) & 1.9 & $0.0035-0.0058$ & TOT & Han et al.(2009) \\
Gwanju, South Korea (Mar-May 2001) & 5.7 & 0.0057 & TOT & Kondo et al. (2006) \\
Hyderabad, India (Jan 2004) & $1.5-11.2$ & 0.0060 & TOT & Park et al. (2005) \\
Karachi, Pakistan (2006-2007) & 5.9 & NA & L. Abs. & Latha et al. (2004) \\
& & & & Dutkiewicz et al. (2009) \\
\hline
\end{tabular}

NA: not available;

TOT: thermal-optical-transmittance;

L Abs.: Light absorption.

Table 6. $\mathrm{BC} / \mathrm{CO}\left(\mu \mathrm{gC} \mathrm{m}{ }^{-3} / \mathrm{ppbv}\right), \mathrm{BC} / \mathrm{CO}_{2}\left(\mu \mathrm{gC} \mathrm{m}{ }^{-3} / \mathrm{ppmv}\right)$, and $\mathrm{CO} / \mathrm{CO}_{2}$ ( $\mathrm{ppbv} / \mathrm{ppmv}$ ) emission ratios derived from emission factors (grams of pollutant evolved per kilogram of fuel burned).

\begin{tabular}{|c|c|c|c|c|c|c|}
\hline & \multicolumn{2}{|c|}{ Transport } & \multirow{2}{*}{$\frac{\text { Industry }}{\text { Coal }^{\mathrm{d}}}$} & \multicolumn{2}{|c|}{ Domestic } & \multirow{2}{*}{$\begin{array}{l}\text { Biomass burning } \\
\text { (crop residue) }^{\mathrm{a}, \mathrm{b}, \mathrm{c}}\end{array}$} \\
\hline & Diesel $^{\mathrm{d}, \mathrm{e}, \mathrm{g}, \mathrm{h}}$ & Gasoline $^{\mathrm{d}, \mathrm{h}}$ & & $\mathrm{Coal}^{\mathrm{d}, \mathrm{f}}$ & biofuels $^{\mathrm{c}, \mathrm{d}}$ & \\
\hline $\mathrm{BC} / \mathrm{CO}$ & $0.0013-0.055$ & $0.0031-0.0115$ & $0.0017-0.0182$ & $0.0019-0.0572$ & $0.0087-0.0266$ & $0.0056-0.016$ \\
\hline $\mathrm{BC} / \mathrm{CO}_{2}$ & 0.15 & $0.06-0.11$ & $0.04-0.74$ & $0.11-3.56$ & $0.69-1.75$ & $0.53-1.10$ \\
\hline $\mathrm{CO} / \mathrm{CO}_{2}$ & $8.6-65.2$ & 33.5 & $23.5-40.4$ & $53.3-62.2$ & $52.9-98.5$ & $45.7-123.6$ \\
\hline
\end{tabular}

${ }^{\mathrm{a}}$ Dhammapala et al. (2007), ${ }^{\mathrm{b}}$ Cao et al. (2008), ${ }^{\mathrm{c}}$ Andreae and Merlet (2001), ${ }^{\mathrm{d}}$ Streets et al. (2003), ${ }^{\mathrm{e}}$ Dickerson et al. (2002), ${ }^{\mathrm{f}}$ Boucher et al. (2008), ${ }^{\mathrm{g}}$ Sanchez et al. (2009), ${ }^{\mathrm{h}}$ Westerdahl et al. (2009).

\subsection{Correlation slopes and emission ratios}

To understand the importance of major emission sources impacting the levels of $\mathrm{BC}, \mathrm{CO}$, and $\mathrm{CO}_{2}$ in the Guangzhou urban region, the slopes of $\triangle \mathrm{BC} / \Delta \mathrm{CO}, \Delta \mathrm{BC} / \Delta \mathrm{CO}_{2}$, and $\Delta \mathrm{CO} / \Delta \mathrm{CO}_{2}$ are compared with the emission ratios derived from emission factors reported for different sources (Table 6). In Table 6 ranges of emission ratios of $\mathrm{BC}$ $\mathrm{CO}, \mathrm{BC}-\mathrm{CO}_{2}$, and $\mathrm{CO}-\mathrm{CO}_{2}$ are presented for different sectors. Although we have seen significant differences in the diurnal variations of the concentrations of primary pollutants depending on the flows from northerly and southerly directions, however, the slopes of $\Delta \mathrm{BC} / \Delta \mathrm{CO}$, $\Delta \mathrm{BC} / \Delta \mathrm{CO}_{2}$ and $\Delta \mathrm{CO} / \Delta \mathrm{CO}_{2}$ do not vary significantly in both types of air masses. As the measurements of northern air can represent the regional-scale emissions in the $\mathrm{PRD}$, here we have compared the observed $\triangle \mathrm{BC} / \Delta \mathrm{CO}$, $\Delta \mathrm{BC} / \Delta \mathrm{CO}_{2}$, and $\Delta \mathrm{CO} / \Delta \mathrm{CO}_{2}$ of northerly air masses with the emission ratios derived from fuel-based emissions factors (Table 6). The observed slopes of $\Delta \mathrm{BC} / \Delta \mathrm{CO}$ (0.0045 $\left.\mu \mathrm{gC} \mathrm{m}^{-3} / \mathrm{ppbv}\right), \Delta \mathrm{BC} / \Delta \mathrm{CO}_{2}\left(0.13 \mu \mathrm{gC} \mathrm{m}^{-3} / \mathrm{ppmv}\right)$, and $\Delta \mathrm{CO} / \Delta \mathrm{CO}_{2}(49.4 \mathrm{ppbv} / \mathrm{ppmv})$ in northerly air masses are within the ranges of emissions ratios estimated for diesel, gasoline and coal from transport, industry, and domestic sectors (Table 6). However, emissions from other sectors may influence the observations of these slopes.
Comparison of observed slopes of $\Delta \mathrm{BC} / \Delta \mathrm{CO}$, $\Delta \mathrm{BC} / \Delta \mathrm{CO}_{2}$, and $\Delta \mathrm{CO} / \Delta \mathrm{CO}_{2}$ with their emission ratios derived from the inventories can be useful to validate the inventory data. Table 7 shows sector-wise emission ratios of $\mathrm{BC} / \mathrm{CO}, \mathrm{BC} / \mathrm{CO}_{2}$, and $\mathrm{CO} / \mathrm{CO}_{2}$ for the urban regions of Guangzhou using the Streets et al. (2003) inventory data for the year 2000 . The slopes of $\Delta B C / \Delta C O$ $\left(0.0045 \mu \mathrm{gC} \mathrm{m}{ }^{-3} / \mathrm{ppbv}\right), \Delta \mathrm{BC} / \Delta \mathrm{CO}_{2}\left(0.13 \mu \mathrm{gC} \mathrm{m}{ }^{-3} / \mathrm{ppbv}\right)$, and $\Delta \mathrm{CO} / \Delta \mathrm{CO}_{2}(49.4 \mathrm{ppbv} / \mathrm{ppmv})$ observed in the northerly air masses are comparable to the emission ratios of $\mathrm{BC} / \mathrm{CO}$, $\mathrm{BC} / \mathrm{CO}_{2}$, and $\mathrm{CO} / \mathrm{CO}_{2}$, respectively, derived for both industrial and transport sectors. The emissions from these two sectors collectively contribute about $70 \%$ of $\mathrm{BC}, 85 \%$ of $\mathrm{CO}$, and $50 \% \mathrm{CO}_{2}$ to the total emissions of these species (Table 1). Thus, the slopes observed in this study tend to validate the emission inventories of $\mathrm{BC}, \mathrm{CO}$, and $\mathrm{CO}_{2}$ from the transport and industrial sectors. However, this conclusion may have limitations mainly due to the limited period of observations in the present study and also due to significant uncertainties in the inventory estimates. The BC-CO, BC- $\mathrm{CO}_{2}$, and $\mathrm{CO}-\mathrm{CO}_{2}$ emission ratios of Guangzhou are agreed reasonably with those of Beijing reported by Han et al. (2009). 
Table 7. Emission ratios of $\mathrm{BC} / \mathrm{CO}\left(\mu \mathrm{gC} \mathrm{m}{ }^{-3} / \mathrm{ppbv}\right), \mathrm{BC} \mathrm{CO}_{2}\left(\mu \mathrm{gC} \mathrm{m}^{-3} / \mathrm{ppmv}\right)$, and $\mathrm{CO} / \mathrm{CO}_{2}$ (ppbv/ppmv) derived from the inventory of Streets et al. (2003). Comparison of the emission ratios of Guangzhou to those of Beijing derived from the total emissions using the same inventory data.

\begin{tabular}{|c|c|c|c|c|c|c|c|}
\hline & \multicolumn{2}{|c|}{ Domestic sector } & \multicolumn{3}{|c|}{ Non-domestic sector } & \multirow[t]{2}{*}{ Guangzhou Total } & \multirow[t]{2}{*}{ Beijing $^{a}$} \\
\hline & Fossils fuel & Biofuel & Industry & Power & Transportation & & \\
\hline $\mathrm{BC} / \mathrm{CO}$ & 0.0225 & 0.0139 & 0.0055 & 0.0087 & 0.0049 & 0.0067 & 0.0050 \\
\hline $\mathrm{BC} / \mathrm{CO}_{2}$ & 0.44 & 0.74 & 0.28 & 0.01 & 0.39 & 0.23 & 0.24 \\
\hline $\mathrm{CO} / \mathrm{CO}_{2}$ & 19.6 & 53.0 & 50.5 & 1.7 & 79.8 & 34.9 & 47.6 \\
\hline
\end{tabular}

a Values taken from Han et al. (2009).

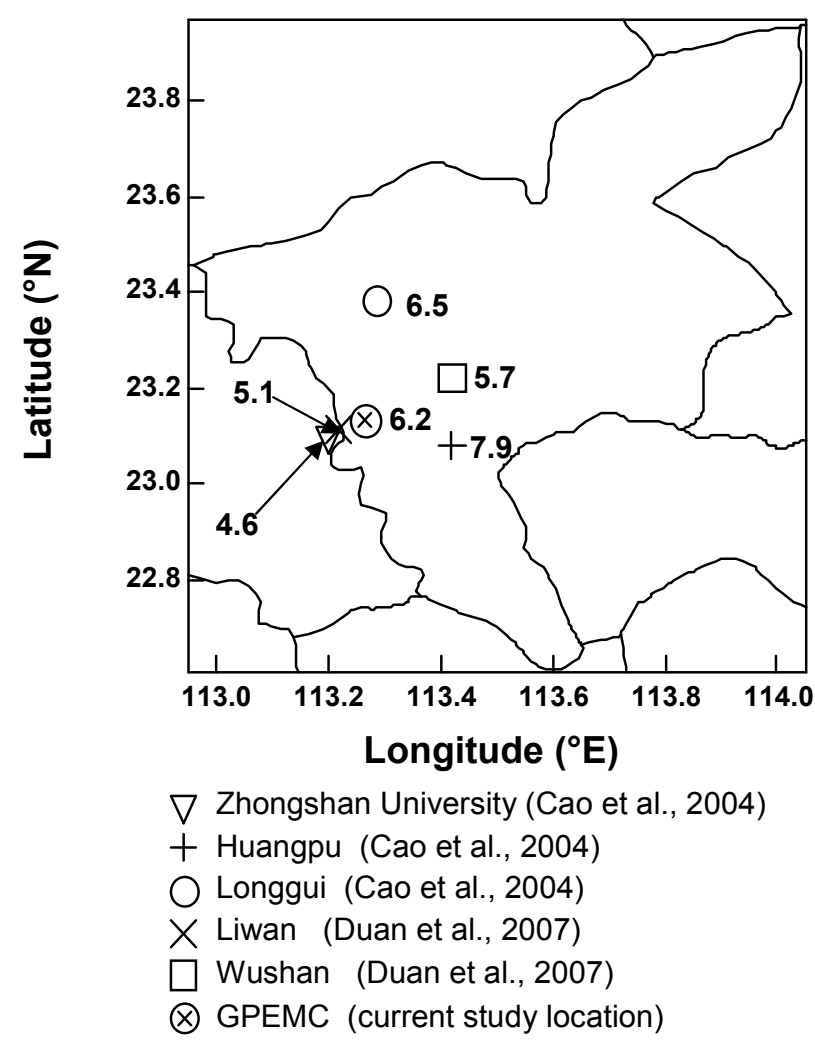

Fig. 10. Comparison of the average BC observed during northerly flows with previous measurements conducted at different sites in Guangzhou in the summer season.

\section{Conclusion}

As part of the PRIDE-PRD 2006 campaign, measurements of mass concentrations of $\mathrm{BC}$ and mixing ratios of $\mathrm{CO}$ and $\mathrm{CO}_{2}$ were conducted at an urban site in Guangzhou, China during July 2006. Major emissions of BC in Guangzhou are from industry, transport, biofuels, and fossils fuels. The average concentrations of $\mathrm{BC}, \mathrm{CO}$, and $\mathrm{CO}_{2}$ were $4.7 \mu \mathrm{gC} \mathrm{m}{ }^{-3}$, $798 \mathrm{ppbv}$ and $400 \mathrm{ppmv}$, respectively, during the campaign. Trends in $\mathrm{BC}, \mathrm{CO}$, and $\mathrm{CO}_{2}$ concentrations were influenced by local meteorology. Trajectory analysis suggests that the observations in northerly air masses represent the emissions from the PRD region, while southerly air masses from the South China Sea tend to dilute the ambient air concentrations of pollutants in Guangzhou. Consequently, the background concentration of $\mathrm{BC}$ in northerly air masses was higher by about a factor of two to those determined for southerly flow. The diurnal patterns of $\mathrm{BC}, \mathrm{CO}$, and $\mathrm{CO}_{2}$ exhibited primary peaks during the morning and secondary peaks in the evening hours coinciding with rush-hour traffic. The ratios of $\mathrm{OC} / \mathrm{BC}$ were lower during the morning rush hours, suggesting the dominance of fresh emissions. The diurnal variations of $\mathrm{BC}, \mathrm{CO}, \mathrm{CO}_{2}$ were stronger in the northerly air masses than those observed in southerly flow. The diurnal patterns of $\mathrm{BC}$ measured during the southerly flow closely follow the patterns of HDV traffic, suggesting their major influence in the variation of primary pollutants. The average concentration of $\mathrm{BC}$ measured during the northerly flow agrees well with previous measurements conducted at different sites in Guangzhou and hence represent the regionalscale emissions of $\mathrm{BC}$ in the PRD. The slopes of $\triangle \mathrm{BC} / \Delta \mathrm{CO}$ (0.0045 $\left.\mu \mathrm{gC} \mathrm{m}^{-3} / \mathrm{ppbv}\right), \Delta \mathrm{BC} / \Delta \mathrm{CO}_{2}\left(0.13 \mu \mathrm{gC} \mathrm{m} \mathrm{m}^{-3} / \mathrm{ppmv}\right)$ and $\Delta \mathrm{CO} / \Delta \mathrm{CO}_{2}(49.4 \mathrm{ppbv} / \mathrm{ppmv})$ observed in northerly air masses agree reasonably with the respective emission ratios.

Acknowledgements. This work was supported by the Ministry of Education, Culture, Sports, Science and Technology (MEXT), the global environment research fund of the Japanese Ministry of Environment (B-083), and the Japanese Science and Technology Agency (JST). This work was conducted as a part of the MegaCities: Asia Task under the framework of the International Global Atmospheric Chemistry (IGAC) project.

Edited by: A. Wiedensohler

www.atmos-chem-phys.net/10/6471/2010/ 


\section{References}

Andreae, M. O. and Metlet, P.: Emission of trace gases and aerosols from biomass burning, Global Biochem. Cy., 15(4) 955-966, 2001.

Andreae, M. O., Schmid, O., Yang, H., Chanda, D., Yu, J. Z., Zeng, L. M., and Zhang, Y. H.: Optical properties and chemical composition of the atmospheric aerosol in urban Guangzhou, China, Atmos. Environ., 42, 6335-6350, 2008.

Alessandrini, F., Schulz, H., Takenaka, S., Lentner, B., Karg, E., Behrendt, H., and Jakob, T.: Effects of ultrafine carbon particle inhalation on allergic inflammation of the lung, J. Allerg. Clinic. Immunolo., 117(4), 824-830, 2006.

Baumgardner, D., Kok, G. L., and Raga, G. B.: On the diurnal variability of particle properties related to light absorbing carbon in Mexico City, Atmos. Chem. Phys., 7, 2517-2526, doi:10.5194/acp-7-2517-2007, 2007.

Bi, X., Sheng, G., Peng, P., Chen, Y., Zhang, Z., and Fu, J.: Distribution of particulate- and vapor-phase n-alkanes and polycyclic aromatic hydrocarbons in urban atmosphere of Guangzhou, China, Atmos. Environ., 37, 289-298, 2003.

Birch, M. E. and Cary, R. A.: Elemental carbon-based method for monitoring occupational exposures to particulate diesel exhaust, Aerosol Sci. Technol., 25, 221-241, 1996.

Bond, T. C., Streets, D. G., Yarber, K. F., Nelson, S. M., Woo, J. H., and Klimont, Z.: A technology-based global inventory of black and organic carbon emissions from combustion, J. Geophys. Res. 109, D14203, doi:10.1029/2003JD003697, 2004.

Boucher, O. and Reddy, M. S.: Climate trade-off between black carbon and carbon dioxide emissions, Energy Policy, 36, 193200, doi:10.1016/j.enpol.2007.08.039, 2008.

Cao, J. J., Lee, S. C., Ho, K. F., Zhang, X. Y., Zou, S. C., Fung, K., Chow, J. C., and Watson, J. G.: Characteristics of carbonaceous aerosol in Pearl River Delta Region, China during 2001 winter period, Atmos. Environ., 37, 1451-1460, 2003.

Cao, J. J., Lee, S. C., Ho, K. F., Zou, S. C., Fung, K., Lib, Y., Watson, J. G., and Chow, J. C.: Spatial and seasonal variations of atmospheric organic carbon and elemental carbon in Pearl River Delta Region, China, Atmos. Environ., 38, 4447-4456, 2004.

Cao, J. J., Lee, S. C., Chow, J. C., Watson, J. G., Ho, K. F., Zhang, R. J., Jin, Z. D., Shen, Z. X., Chen, G. C., Kang, Y. M., Zou, S. C., Zhang, L. Z., Qi, S. H., Dai, M. H., Cheng, Y., and $\mathrm{Hu}, \mathrm{K}$.: Spatial and seasonal distributions of carbonaceous aerosols over China, J. Geophys. Res., 112, D22S11, doi:10.1029/2006JD008205, 2007.

Cao, J. J., Zhu, C. S., Chow, J. C., Watson, J. G., Han, Y. M., Wang, G. H., Shen, Z. X., and An, Z. S.,: Black carbon relationships with emissions and meteorology in Xi' an, China, Atmos. Res., 94, 194-202, 2009.

Cao, G., Zhang, X., Gong, S., and Zheng, F.: Investigation on emission factors of particulate matter and gaseous pollutants from crop residue burning, J. Environ. Sc. 20, 50-55, 2007.

Cheung, H. C., Wang, T., Baumann, K., and Guo, H.: Influence of regional pollution outflow on the concentrations of fine particulate matter and visibility in the coastal area of southern China, Atmos. Environ., 39, 6463-6474, 2005.

Cheng, Y. F., Eichler H., Wiedensoler, A., Heintzenberg, J., Zhang, Y. H., Hu, M., Herrmann H., Zeng, L. M., Liu, S., Gnauk, T., Bruggermann, E., and He, L. Y.: Mixing state of elemental carbon and non-light-absorbing aerosol components derived from in situ particle optical properties at Xinken in Pearl River Delta of China, J. Geophys. Res., 111, D20204, doi:10.1029/2005JD006929, 2006.

Chuang, P. Y., Duvall, R. M., Bae, M. S., Jefferson, A., Schauer, J. J., Yang, H., Yu, J. Z., and Kim, J.: Observations of elemental carbon and absorption during ACE-Asia and implications for aerosol radiative properties and climate forcing, J. Geophys. Res., 108(D23), 8634, doi:10.1029/2002JD003254, 2003.

Dhammapala, R., Claiborn, C., Simpson, C., and Jimenez, J.: Emission factors from wheat and Kentucky bluegrass stubble burning: Comparison of field and simulated burn experiments, Atmos. Environ., 41, 1512-1520, doi:10.1016/j.atmosenv.2006.10.008, 2007.

Dickerson, R. R., Andreae, M. O., Campos, T., Mayol-Bracero, O. L., Neusuess, C., and Streets, D. G.: Analysis of black carbon and carbon monoxide observed over the Indian Ocean: Implications for emissions and photochemistry, J. Geophys. Res., 107(D19), 8017, doi:10.1029/2001JD000501, 2002.

Draxler, R. R. and Rolph, G. D.: HYSPLIT (HYbrid Single-Particle Lagrangian Integrated Trajectory) Model access via NOAA ARL READY, Website (http://www.arl.noaa.gov/ready/hysplit4.html), NOAA Air Resources Laboratory, Silver Spring, MD, 2003.

Duan, J., Tan, J., Cheng, D., Bi, X., Deng, W., Sheng, G., Fu, J., and Wong, M. H.: Sources and characteristics of carbonaceous aerosol in two largest cities in Pearl River Delta Region, China, Atmos. Environ., 41, 2895-2903, 2007.

Dutkiewicz, V. A., Alvi, S., Ghauri, B. M., Choudhary, M. I., and Husain, L.: Black carbon aerosols in urban air in South Asia, Atmos. Environ., 43, 1737-1744, doi:10.1016/j.atmosenv.2008.12.043, 2009.

Garland, R. M., Yang, H., Schmid, O., Rose, D., Nowak, A., Achtert, P., Wiedensohler, A., Takegawa, N., Kita, K., Miyazaki, Y., Kondo, Y., Hu, M., Shao, M., Zeng, L. M., Zhang, Y. H., Andreae, M. O., and Pöschl, U.: Aerosol optical properties in a rural environment near the mega-city Guangzhou, China: implications for regional air pollution, radiative forcing and remote sensing, Atmos. Chem. Phys., 8, 5161-5186, doi:10.5194/acp-85161-2008, 2008.

Glasiusa, M., Ketzel, M., Wahlin, P., Jensen, B., Mønster, J., Berkowicz, R., and Palmgren, F.: Impact of wood combustion on particle levels in a residential area in Denmark, Atmos. Environ., 40, 7115-7124, 2006.

Han, S., Kondo, Y., Takegawa, N., Miyazaki, Y., Oshima, N., Hu, M., Lin, P., Deng, Z., Zhao, Y., and Sugimoto, N.: Temporal variation of elemental carbon in Beijing, J. Geophys. Res., 114, D23202, doi:10.1029/2009JD012027, 2009.

Hansen, A. D. A., Convey, T. J., Steele, L. P., Bodhaine, B. A., Thoning, K. W., Tans, P., and Novakov, T.: Correlations among combustion effluent species at Barrow, Alaska: Aerosol black carbon, carbon dioxide, and methane, J. Atmos. Chem., 9, 283299, 1989.

Ho, K. F., Lee, S. C., Cao, J. J., Li, Y. S., Chow, J. C., Watson, J. G., and Fung, K.: Variability of organic and elemental carbon, water soluble organic carbon, and isotopes in Hong Kong, Atmos. Chem. Phys., 6, 4569-4576, doi:10.5194/acp-6-4569-2006, 2006.

Huang, Y., Chameides, W. L., and Dickinson, R. E.: Direct and indirect effects of anthropogenic aerosols on regional precipitation over east Asia, J. Geophys. Res., 112, D03212, 
doi:10.1029/2006JD007114, 2007.

Intergovernmental Panel on Climate Change (IPCC), available online at:, http://www.grida.no/publications/other/ipcc_tar/?src= /climate/ipcc_tar/, 2001.

Jacobson, M. Z.: A Physically-Based Treatment of Elemental Carbon Optics: Implications for Global Direct Forcing of Aerosols, Geophys. Res. Lett., 27(2), 217-220, 2000.

Jansen, K. L., Larson, T. V., Koenig, J. Q., Mar, T. F., Fields, C., Stewart, J., and Lippmann, M.: Associations between Health Effects and Particulate Matter and Black Carbon in Subjects with Respiratory Disease, Environ. Health Perspect., 113, 1741-1746, 2005.

Jeong, C. H., Hopke, P. K., Kim, E., and Lee, D. W.: The comparison between thermal-optical transmittance elemental carbon and Aethalometer black carbon measured at multiple monitoring sites, Atmos. Environ., 38, 5193-5204, 2004.

Jung, J. S., Lee, H., Kim, Y. J., Liu, X., Zhang, Y., Gu, J., and Fan, S.: Aerosol chemistry and the effect of aerosol water on visibility impairment and radiative forcing in Guangzhou during the 2006 Pearl River Delta campaign (PRIDE-PRD2006), J. Environ. Manage., 90, 3231-3244, 2009.

Kim, D. and Ramanathan, V.: Solar radiation budget and radiative forcing due to aerosols and clouds, J. Geophys. Res., 113, D02203, doi:10.1029/2007JD008434, 2008.

Kim, Y. J., Kim, M. J., Lee, K. H., and Park, S. S.: Investigation of carbon pollution episodes using semi-continuous instrument in Incheon, Korea, Atmos. Environ., 40, 4064-4075, 2006.

Kondo, Y., Komazaki, Y., Miyazaki, Y., Moteki, N., Takegawa, N., Kodama, D., Deguchi, S., Nogami, M., Fukuda, M., Miyakawa, T., Morino, Y., Koike, M., Sakurai, H., and Ehara, K.: Temporal variations of elemental carbon in Tokyo, J. Geophys. Res., 111, D12205, doi:10.1029/2005JD006257, 2006.

Kondo, Y., Sahu, L., Moteki, N., Khan, F., Takegawa, N., Liu, X., and Koike, M.: Consistency and traceability of black carbon measurements made by laser-induced incandescence, thermal optical transmittance, and filter-based photo-absorption technique, Aerosol Sci. Technol., in review, 2010.

Lai, S. C., Zou, S. C., Cao, J. J., Lee, S. C., and Ho, K. F.: Characterizing ionic species in PM2.5 and PM10 in four Pearl River Delta cities, South China, J. Environ. Sc., 19, 939-947, ISSN:10010742, CN 11-2629/X, 2007.

Latha, K. M. and Badarinath, K. V. S.: Correlation between black carbon aerosols, carbon monoxide and tropospheric ozone over a tropical urban site, Atmos. Res., 71, 265-274, 2004.

Lin, P., Hu, M., Deng, Z., Slanina, J., Han, S., Kondo, Y., Takegawa, N., Miyazaki, Y., Zhao, Y., and Sugimoto, N.: Seasonal and diurnal variations of organic carbon in PM2.5 in Beijing and the estimation of secondary organic carbon, J. Geophys. Res., 114, D00G11, doi:10.1029/2008JD010902, 2009.

Liu, X., Cheng, Y., Zhang, Y., Jung, J., Sugimoto, N., Chang, S. Y., Kim, Y. J., Fan, S., and Zeng, L.: Influences of relative humidity and particles chemical composition on aerosol scattering properties during the 2006 PRD campaign, Atmos. Environ., 42, 1525-1536, 2008.

Menon S., Hansen, J., Nazarenko, L., and Luo, Y.: Climate effects of black carbon aerosols in China and India, Science, 297, 22502253, doi:10.1126/science.1075159, 2002.

Miyazaki, Y., Kondo, Y., Sahu, L. K., Imaru, J., Fukushima, N, and Kano, M.: Performance of a newly designed continuous soot monitoring system (COSMOS), J. Environ. Monit., 10, 11951201, 2008.

Park, S. S, Kim, Y. J., and Fung, K.: PM2.5 carbon measurements in two urban areas: Seoul and Kwangju, Korea, Atmos. Environ, 36, 1287-1297, 2002

Park, S. S., Bae, M. S., Schauer, J. J., Ryu, S. S., Kim, Y. J., Cho, S. Y., and Kim, S. J.: Evaluation of the TMO and TOT methods for OC and EC measurement and their characteristics in PM2.5 at an urban site of Korea during ACE-Asia, Atmos. Environ., 39, 5101-5112, 2005.

Park, S. S., Kim, Y. J., and Kang, C. H.: Polycyclic aromatic hydrocarbons in bulk PM2.5 and size-segregated aerosol particle samples measured in an urban environment, Environ. Monit. Assess. 128, 231-240, doi:10.1007/s10661-006-9308-4, 2007.

Park, R. J., Jacob, D. J., Palmer, P. I , Clarke, A. D., Weber, R. J., Zondlo, M. A., Eisele, F. L., Bandy, A. R., Thornton, D. C., Sachse, G. W., and Bond, T. C.: Export efficiency of black carbon aerosol in continental outflow: Global implications, J. Geophys. Res., 110, D11205, doi:10.1029/2004JD005432, 2005.

Polidori, A., Turpin, B. J., Lim, H. J., Cabada, J. C., Subramanian, R., Pandis, S. N., and Robinson, A. L.: Local and Regional Secondary Organic Aerosol: Insights from a Year of Semi-Continuous Carbon Measurements at Pittsburg, Aerosol Sci. Technol., 40, 861-872, 2006.

Ramanathan, V. and Carmichael, G.: Global and regional climate changes due to black carbon, Nature Geosci., 1, 221-227, doi:10.1038/ngeo156, 2008.

Sahu, L. K., Kondo, Y., Miyazaki, Y., Kuwata, M., Koike, M., Takegawa, N., Tanimoto, H., Matsueda, H., Yoon, S. C., and Kim, Y. J.: Anthropogenic aerosols observed in Asian continental outflow at Jeju Island, Korea, in spring 2005, J. Geophys. Res., 114, D03301, doi:10.1029/2008JD010306, 2009.

Sanchez-Ccoyllo, O. R., Ynoue, R. Y., Martins, L. D., Astolfo, R., Miranda, R. M., Freitas, E. D., Borges, A. S., Fornaro, A., Freitas, H., Moreira, A., and Andrade, M. F.: Vehicular particulate matter emissions in road tunnels in Sao Paulo, Brazil, Environ. Monit. Assess., 149, 241-249, doi:10.1007/s10661-008-0198-5, 2009.

Shao, M., Tang, X., Zhang, Y., and Li, W.: City clusters in China: Air and surface water pollution, Front. Ecol. Environ., 4(7), 353361, 2006.

Shao, M. and Zhang, Y.:Current Air quality problem and control strategies for Vehicular emissions in China, available online at: http://www.walshcarlines.com/china/china.airquality. minshao.pdf, 2001.

Streets, D. G., Bond, T. C., Carmichael, G. R., Fernandes, S. D., Fu, Q., He, D., Klimont, Z., Nelson, S. M., Tsai, N. Y., Wang, M. Q., Woo, J. H., and Yarber, K. F.: An inventory of gaseous and primary aerosol emissions in Asia in the year 2000, J. Geophys. Res., 108(D21), 8809, doi:10.1029/2002JD003093, 2003.

Suglia, S. F., Gryparis, A., Wright, R. O., Schwartz, J., and Wright, R. J.: Association of black carbon with cognition among children in a prospective birth cohort study, Am. J. Epidemiol., 167(3), 80-286, 2008

Sugimoto, N., Nishizawa, T., Liu, X., Matsui, I., Shimizu, A., Zhang, Y., Li, R., and Liu, J.: Continuous observations of aerosol profiles with a two- wavelength Mie- cattering lidar in Guangzhou in PRD2006, J. Appl. Meteorol. Climatol., 48, 1822 1830, doi:10.1175/2009JAMC2089.1, 2009. 
Takegawa, N., Kondo, Y., Koike, M., Chen, G., Machida, T., Watai, T., Blake, D. R., Streets, D. G., Woo, J. H., Carmichael, G. R., Kita, K., Miyazaki, Y., Shirai, T., Liley, J. B., and Ogawa, T.: Removal of NOx and NOy in Asian outflow plumes: Aircraft measurements over the western Pacific in January 2002, J. Geophys. Res., 109, D23S04, doi:10.1029/2004JD004866, 2004.

Takegawa, N., Miyakawa, T., Kondo, Y., Jimenez, J. L., Zhang, Q., Worsnop, D. R., and Fukuda, M.: Seasonal and diurnal variations of submicron organic aerosol in Tokyo observed using the Aerodyne aerosol mass spectrometer, J. Geophys. Res., 111, D11206, doi:10.1029/2005JD006515, 2006.

Takegawa, N., Miyakawa, T., Kuwata, M., Kondo, Y., Zhao, Y., Han, S., Kita, K., Miyazaki, Y., Deng, Z., Xiao, R., Hu, M., van Pinxteren, D., Herrmann, H., Hofzumahaus, A., Holland, F., Wahner, A., Blake, D. R., Sugimoto, N., and Zhu, T.: Variability of submicron aerosol observed at a rural site in Beijing in the summer of 2006, J. Geophys. Res., 114, D00G05, doi:10.1029/2008JD010857, 2009.

Tan, J. H., Bi, X. H., Duan, J. C., Rahn, K. A., Sheng, G. Y., and Fu, J. M.: Seasonal variation of particulate polycyclic aromatic hydrocarbons associated with PM10 in Guangzhou, China, Atmos. Res., 80, 250-262, 2006.

Turpin, B. J. and Huntzicker, J. J.: Secondary formation of organic aerosol in the Los Angeles basin: A descriptive analysis of organic and elemental carbon concentrations, Atmos. Environ., 25A, 207-215, 1991.

Turpin, B. J. and Huntzicker, J. J.: Identification of secondary organic aerosol episodes and quantitation of primary and secondary organic aerosol concentrations during SCAQS, Atmos. Environ, 29, 3527-3544, 1995.
Venkatachari, P., Zhou, L., Hopke, P. K., Schwab, J. J., Demerjian, K. L., Weimer, S., Hogrefe, Olga H., Felton, D. and Rattigan, O.: An intercomparison of measurement methods for carbonaceous aerosol in the ambient air in New York City, Aerosol Sci. Tech., 25(10), 788-795, 2006.

Westerdahl, D., Wang, X., Pan, X., and Zhang, K. M.: Characterization of on-road vehicle emission factors and microenvironmental air quality in Beijing, China, Atmos. Environ., 42, 697-705, 2009.

Xie, S, Zhang, Y., Qi, L., and Tang, X.: Spatial distribution of traffic-related pollutant concentrations in street canyons, Atmos. Environ., 37, 3213-3224, 2003.

Xiao, R., Takegawa, N., Kondo, Y., Miyazaki, Y., Miyakawa, T., Hu, M., Shao, M., Zeng, L. M., Hofzumahaus, A., Holland, F., Lu, K., Sugimoto, N, Zhao, Y., and Zhang, Y. H.: Formation of submicron sulfate and organic aerosols in the outflow from the urban region of the Pearl River Delta in China, Atmos. Environ., 43, 3754-3763, 2009.

Yang, L., Zhang, X., Gong, S., Che, H. Wang, Qu, W., and Sun, J.: Comparison of EC and $\mathrm{BC}$ and evaluation of dust aerosol contribution to light absorption in Xi' an, China, Environ. Monit. Assess., 120, 301-312, 2006.

Yeung, M. C., Lee, S. C., Lun, B. H., and Tanner, P. A.: Summer rain events in south-east Asia: Spatial and temporal variations, Atmos. Res., 86, 241-248, 2007.

Zhou, K., Ye, Y. H., Liu, Q., Liu, A. J., and Peng, H. L.: Evaluation of ambient air quality in Guangzhou, China, J. Environ. Sci., 19, 432-437, 2007. 